\title{
Evolution of the boundary between the Philippine Sea Plate and Australia: palaeomagnetic evidence from eastern Indonesia
}

\author{
Jason R. Ali ${ }^{a}$, Robert Hall ${ }^{\mathrm{b}}$ \\ "Department of Oceanography, The University, Southampton, SO9 5NH, UK \\ ${ }^{\mathrm{b}}$ Department of Geological Sciences, University College London, Gower Street, London, WCIE 6BT, UK
}

Received 23 March 1994; accepted 10 March 1995

\begin{abstract}
The boundary between the Philippine Sea and Australian plates is the left-lateral Sorong Fault system of eastern Indonesia. Until recently, modelling this boundary for the period before about $5 \mathrm{Ma}$ was difficult; the Tertiary motion of the Philippine Sea Plate was uncertain and palaeomagnetic data from areas adjacent to the fault were lacking. Recent geological and palaeomagnetic studies of the area north of the Sorong Fault have elucidated the Tertiary motion history of the Philippine Sea Plate, providing a reference for examining movements within the fault system. We report new palaeomagnetic data from within the Sorong Fault Zone, from the islands of Taliabu and Obi. Taliabu is part of the Sula Platform and is considered to be derived from Australia. Pelagic limestones from the Upper Cretaceous Tanamu Formation of Taliabu yielded a direction of $D=329.1^{\circ}, I=-34.9^{\circ}$ implying counter-clockwise rotation and a formation latitude of $19 \pm 5^{\circ} \mathrm{S}$. Sula and Misool are postulated to be part of a single microcontinent which had a different Late Cretaceous-mid-Tertiary movement history from Australia. The Sula Platform was transported to its present position by movement along the Sorong Fault system in the Late Miocene. Obi includes rocks of Philippine Sea and Australian origin; all the new sites are in rocks of Philippine Sea Plate origin. Since the Early Neogene the Philippine Sea Plate, which includes all islands north of the Sorong Fault, has rotated $40^{\circ}$ clockwise and moved $10-15^{\circ}$ northwards. Philippine Sea Plate rocks within the Sorong Fault Zone record similar latitude shifts, but different rotations. In north Obi, the Upper Oligocene Anggai River Formation and the Middle Miocene Woi Formation record $\sim 60^{\circ}$ and $\sim 30^{\circ}$ counter-clockwise rotations, respectively. The sense of rotation is consistent with motion within a left-lateral fault system, with the Philippine Sea and Australian plates providing the shear couple. In contrast, the Woi Formation in southeast Obi records $15-20^{\circ}$ clockwise rotation; this area is separated from the zone of counter-clockwise movement in north Obi by a strand of the Sorong Fault. Arc volcaniclastic rocks from the Upper Cretaceous Leleobasso Formation of northwest Obi have a primary magnetisation with a mean direction of $D=357.1^{\circ}$, $I=-21.9^{\circ}$. These rocks formed at $\sim 11^{\circ} \mathrm{N}$ or $\sim 11^{\circ} \mathrm{S}$, depending on the interpreted rotation history, and indicate a Pacific rather than Indian Ocean origin. A volcanic arc at the southern edge of the Philippine Sea Plate collided with eastern New Guinea at $\sim 25 \mathrm{Ma}$. The Philippine Sea-Australia plate boundary then changed from subduction to strike-slip, as the Philippine Sea Plate began its Neogene rotation, initiating the Sorong Fault system. We suggest that many of the arc fragments in the New Guinea orogenic belt originated in the southern Philippine Sea Plate arc which has subsequently been dismembered by strike-slip faulting.
\end{abstract}




\section{Introduction}

The Sorong Fault at the northern margin of New Guinea is part of one of the world's major fault systems and forms the western end of a zone of left-lateral strike-slip faulting resulting from the oblique convergence of Australia and the Pacific (Fig. 1). It marks the western segment of the north- ern New Guinea fault system, first interpreted as a left-lateral megashear by Carey (1958) and incorporated in many tectonic descriptions of the region (e.g. Hamilton, 1979; Dow and Sukamto, 1984). We use the term "Sorong Fault Zone" to include the region from the Bird's Head to east Sulawesi (Fig. 1). The area includes fragments of crust of continental, arc and oceanic origin and it has been suggested
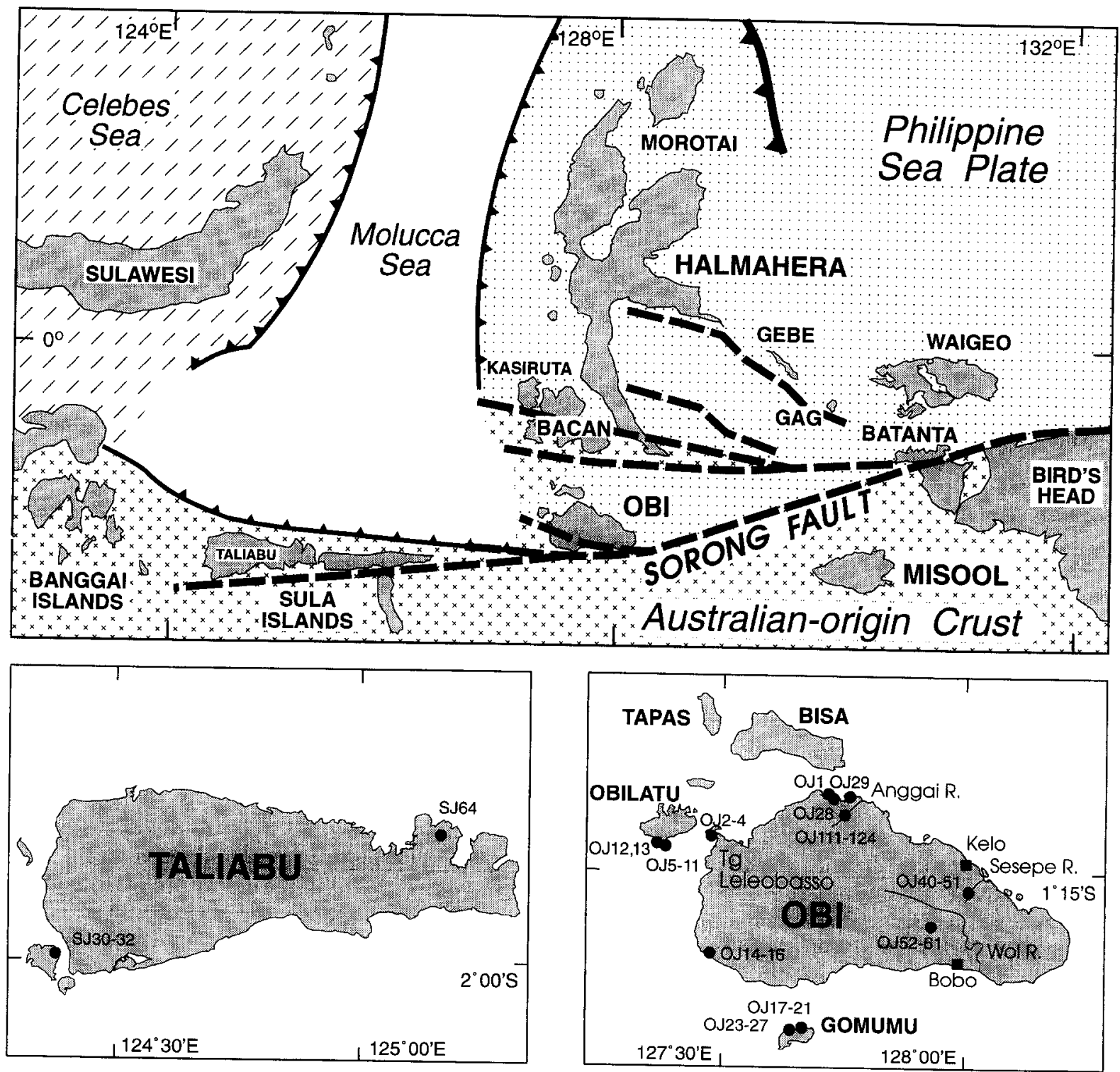

Fig. 1. Sorong Fault Zone, eastern Indonesia. Principal areas of crust of Australian origin and Philippine Sea Plate origin are ornamented. The Molucca Sea is currently thrusting outwards towards the colliding volcanic arcs of Halmahera and north Sulawesi. The locality maps for Taliabu and Obi show palaeomagnetic sites sampled during this project. 
as a modern analogue of ancient orogenic belts composed of terranes, such as the North American Western Cordillera (Silver and Smith, 1983).

Several models have been proposed to account for the presence of continental fragments in the region, all of which accept that the continental crust is of Australian origin. Hamilton (1979) illustrated a model popularly known as the "bacon-slicer" which suggests that crustal fragments were sliced and moved westwards from the leading edge of the Bird's Head as it moved north into a fault system bounding the Pacific region. Pigram et al. (1985) postulated that the Sula platform, today located at the western end of the Sorong Fault system immediately to the east of Sulawesi, was derived originally not from the Bird's Head but from the northern Australian continental margin in central or eastern New Guinea. They based their proposal on stratigraphic similarities although without specifying the timing of separation of Sula from Australia or the mechanism of transport to its present position. Charlton (1986), in a version of the bacon-slicer model combined with indentor tectonics, proposed that NE-SW-oriented faults sliced continental crust into an amalgamating orogenic belt left by the passage of Australia past Southeast Asia. More recently, Pigram and Davies (1987) argued that the northern New Guinea margin is composed of terranes which have docked, principally by collision, during the motion of Australia into the Pacific. The role or importance of strike-slip faulting is not discussed by them. Rangin et al. (1990) and Daly et al. (1991) incorporated some of the suggestions made by these models into a plate reconstruction of the Southeast Asian region although for the Sorong Fault Zone these reconstructions remain somewhat uncertain.

All of the models considering the development of eastern Indonesia have been hampered by the lack of detailed geological information. The geological history of the region is relatively poorly known and the motion history of the fragments within and adjacent to the Sorong Fault system is poorly understood. Furthermore, the history of motion of the Philippine Sea Plate, one of the major pieces in the jig-saw, has been controversial because it is bounded by subduction zones which isolate it from the oceanic-ridge reference frame. Until recently, well-constrained reconstructions have been attempted only for relatively small areas of eastern Indonesia (e.g. Hall, 1987; Hall and Nichols, 1990) and have been feasible only for a period up to $\sim 10 \mathrm{Ma}$. Eastern Indonesia and the adjacent area of the west Pacific has been a large gap which it has been possible to interpret in a variety of ways.

The geological information presented here is based on fieldwork with the Indonesian Geological Research and Development Centre (GRDC) carried out in 1984, 1987 and 1988 (Hall, 1987; Hall et al., 1988a, b, 1991; Hall and Nichols, 1990; Charlton et al., 1991; Nichols and Hall, 1991) and more recent, largely unpublished, results of fieldwork carried out in 1989 and 1990 as part of the Sorong Fault Zone project. A principal aim of this project has been to provide a sound stratigraphic basis, using biostratigraphic and isotopic dating, for a tectonic understanding of the region. During the 1989 and 1990 expeditions we carried out systematic palaeomagnetic sampling of most of the formations on Halmahera, offshore islands west of Halmahera, Gebe, Gag, Waigeo, Batanta, Bacan and surrounding islands, Obi and surrounding islands, the islands of the Sula-Banggai Group, and parts of east Sulawesi (Fig. 1). Results of the palaeomagnetic work dealing with the Philippine Sea Plate motion history, determined from the area north of the Sorong Fault, are reported in Hall et al. (1995a, b-this issue) and these provide the basis for tectonic reconstructions of the Philippine Sea Plate and Australian margin. Here we discuss the palaeomagnetic results bearing on the movement of fragments in the Sorong Fault system, and the implications of the reconstructions for the development of the fault system.

\section{Regional geology}

\subsection{Present tectonic setting of eastern Indonesia}

Hamilton's (1979) account of Indonesian tectonics remains the most comprehensive overview of the region although tectonic interpretations have been modified by investigations of the marine geology (e.g. Silver and Moore, 1978; Moore and Silver, 1983; Silver et al., 1983), regional seismicity (Cardwell et al., 1980; McCaffrey, 1982), and land geology (e.g. Dow and Sukamto, 1984; Pigram and 


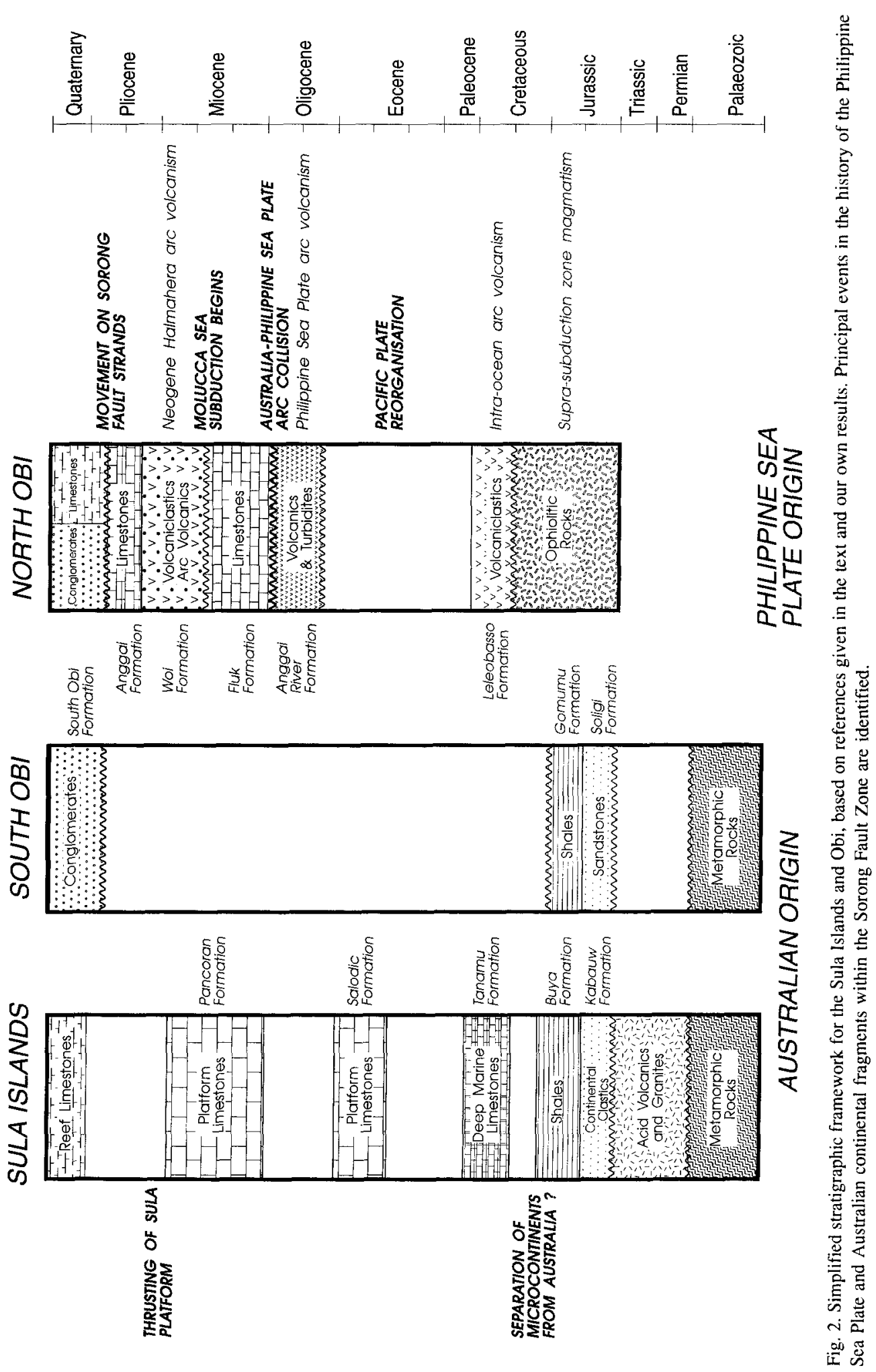


Davies, 1987; Hall, 1987; Hall and Nichols, 1990). Eastern Indonesia includes the junction between the Eurasian, Australian and Philippine Sea plates. In eastern Indonesia, Australia is moving NNE at about $75 \mathrm{~mm} / \mathrm{yr}$ (DeMets et al., 1990) and the Philippine Sea Plate moves WNW at about $100 \mathrm{~mm} / \mathrm{yr}$ (Ranken et al., 1984; Seno et al., 1993). The Philippine arcs, a complex of modern and ancient island arc and continental fragments, terminate southwards in the Molucca Sea Collision Zone where the opposed Halmahera and Sangihe Arcs are actively converging. The southern boundary of both the Molucca Sea and the Philippine Sea plates is the Sorong Fault system. The Sorong Fault has its type locality in the northern Bird's Head region of New Guinea (Visser and Hermes, 1962; Tjia, 1973; Dow and Sukamto, 1984). Extending NW from the Bird's Head are several Pliocene-Recent left-lateral splays of the Sorong Fault. West of the Bird's Head the fault system splays into the Molucca-Sorong Fault, the North Sula-Sorong Fault (Hamilton, 1979) and the Buru Fracture (Tjokosapoetro and Budhitrisna, 1982).

\subsection{The Sorong Fault Zone}

The Sorong Fault system juxtaposes continental, arc and ophiolitic rocks. Fragments of continental crust derived from the Australian margin are found within or adjacent to the Sorong Fault system and include high-grade metamorphic rocks of probable Palaeozoic or greater age and Jurassic sedimentary rocks, representing the cover to the metamorphic basement (Brouwer, 1924; Van Bemmelen, 1949; Hamilton, 1979; Hall et al., 1988a, 1991).

Crust of Philippine Sea Plate origin (Fig. 2) has a basement of ophiolitic and arc rocks (Hall, 1987; Hall et al., 1988a, b, 1991, 1995b-this issue; Hall and Nichols, 1990; Charlton et al., 1991; Nichols and Hall, 1991). The ophiolites are remnants of a Mesozoic intra-oceanic arc overlain by, and imbricated with, Upper Cretaceous-Eocene arc volcanic and sedimentary rocks. Arc plutonic rocks intrude the ophiolites and sedimentary rocks. The basement rocks are overlain by shallow-water Upper Eocene limestones and an Oligocene arc-related extensional sequence including basaltic pillow lavas and volcaniclastic turbidites. Arc activity in the Sorong Fault Zone region continued until the earliest Miocene when collision between the south-facing Philippine Sea Plate arc and the Australian continental margin occurred. The boundary between the Philippine Sea and Australian plates then became a transform boundary with the initiation of the left-lateral Sorong Fault (Hall et al., 1995a). Fragments of Australian and Philippine Sea Plate origin have a common stratigraphic history during the Neogene and there was no significant volcanic activity at the Australian-Philippine Sea boundary. Arc activity started and ceased earliest in the south, in Obi, beginning in the late Middle Miocene and terminating at the beginning of the Pliocene. Further north, arc activity continues today in the northern part of the Halmahera arc.

\subsection{Geology of $\mathrm{Obi}$}

Our knowledge of the geology of Obi is based upon early Dutch reconnaissance studies (Wanner, 1913; Brouwer, 1924), mapping by GRDC (Sudana and Yasin, 1983), and our own studies (Hall et al., 1991; and unpubl. results). Obi can be divided into two parts with different pre-Miocene geological histories (Fig. 2). The major part of the island (Fig. 3), in the north, has a basement of Mesozoic ophiolitic rocks, Upper Cretaceous arc volcaniclastic sedimentary rocks of the Leleobasso Formation and the Oligocene Anggai River Formation arc volcanic and volcaniclastic rocks. Diorite plutons intrude the ophiolitic and Cretaceous rocks in west Obi. These rocks are the equivalent of similar but more complete sequences of Halmahera and Waigeo and have a Philippine Sea origin.

On the islands of Bisa and Tapas, immediately northwest of Obi, are high-grade metamorphic rocks similar to those exposed on Bacan $50 \mathrm{~km}$ to the north. Metabasic rocks in this complex yield radiometric ages $>100 \mathrm{Ma}$ and are interpreted as metamorphosed Philippine Sea Plate ophiolitic rocks (S.J. Baker, pers. commun., 1992). Continental metamorphic rocks, including garnet-kyanite schists and gneisses, are presumed to be Palaeozoic or older and to be derived from the Australian continental margin. Isotopic ages from these rocks on Obi and Bacan have so far yielded very young ages which are reset by Neogene volcanic and hydrothermal activity (Baker and Malaihollo, 1995). The continental meta- 
morphic rocks probably form the basement in southwest Obi where they are found as float samples in rivers and there is a series of Mesozoic sediments unlike any of the Philippine Sea Plate rocks. The Soligi Formation is a series of decalcified sandstones and siltstones which contain fragments of Pentacrinus, indicating a Lower Jurassic age. They are notable in containing detrital quartz which is absent in all Philippine Sea Plate rocks. Wanner (1913) reported Jurassic ammonites as float in southwest Obi. In southwest Obi and on the small island of Gomumu to the south there are siltstones and shales of the Gomumu Formation. This formation locally contains a rich fauna including ammonite fragments, aptychi, belemnites and bivalves. The palynomorphs and belemnites indicate Middle-Upper Jurassic ages. The Soligi and Gomumu formations are closely similar to Jurassic rocks of the Australian margin known throughout eastern Indonesia.
The major part of Obi is overlain locally by Miocene shallow-water limestones and then by a thick sequence of Middle-Upper Miocene volcanic and volcaniclastic rocks of the Woi Formation. Much of the volcanic sequence consists of sub-aerial products indicating proximity to the Late Miocene volcanic centre(s). These are the oldest products of the Halmahera volcanic arc and are overlain in north $\mathrm{Obi}$ by Pliocene limestones and in south Obi by PlioPleistocene conglomerates and sandstones.

\subsection{Geology of the Sula Islands}

The Banggai-Sula Islands have a stratigraphic sequence (Fig. 2) ranging in age from Palaeozoic to Quaternary (Pigram et al., 1985; Garrard et al., 1988). The oldest rocks are slates and schists deformed in the Late Palaeozoic and intruded by Permo-Triassic granites and overlain by Permo-Tri-

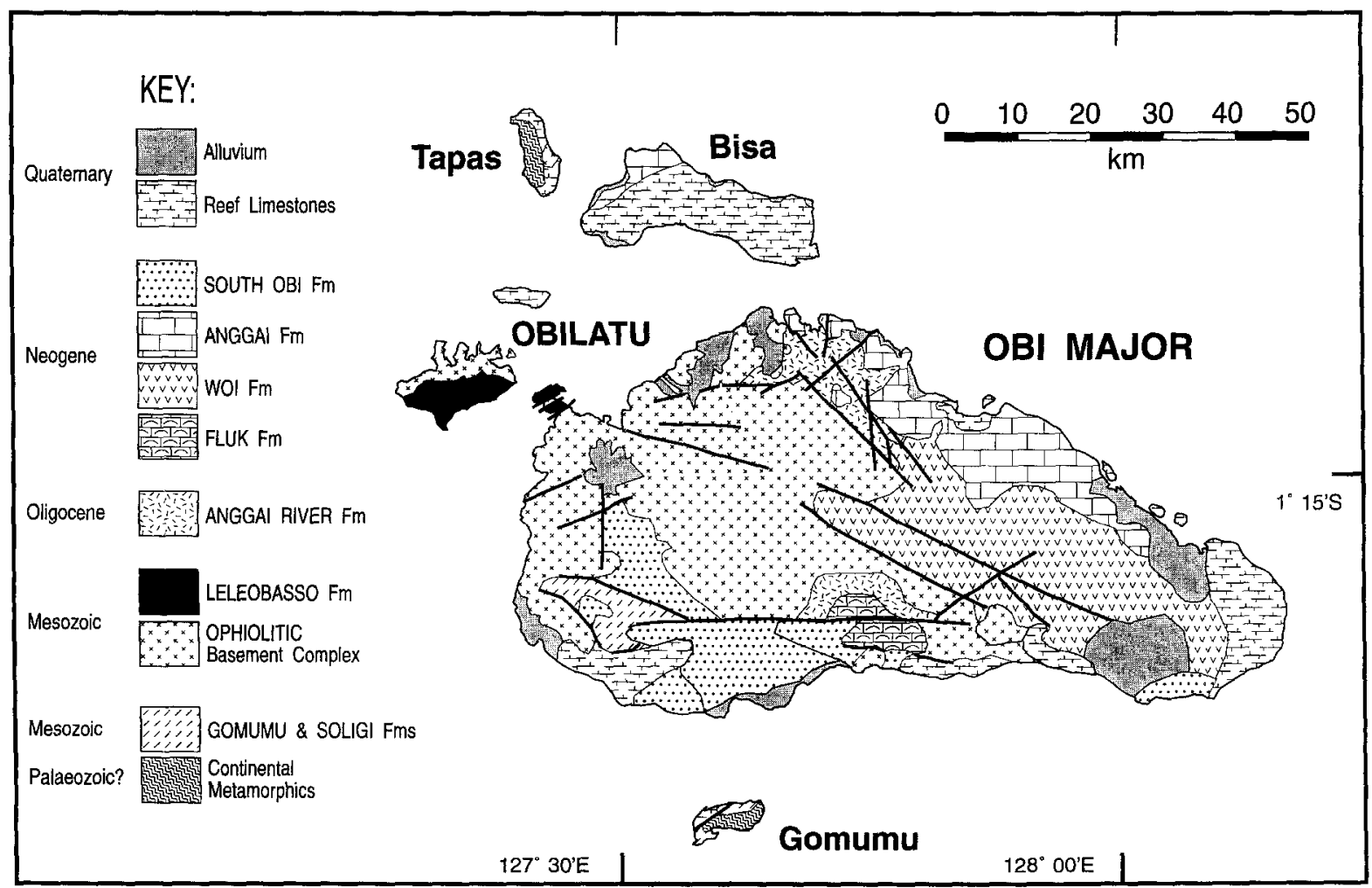

Fig. 3. Simplified geological map of Obi based upon references cited in the text and our unpublished mapping. 
assic acid volcanics. These basement rocks are unconformably covered by continental and shallowmarine coarse-grained clastic sedimentary rocks of the Jurassic Kabauw and Bobong formations. Marine shales of the Upper Jurassic-Lower Cretaceous Buya Formation succeed these conformably. On Taliabu and Mangole the Buya Formation is overlain by deep-marine carbonates of the Tanamu Formation. Elsewhere in the area, Eocene, Miocene and Quaternary shallow-water limestones rest unconformably upon the older formations.

\section{Palaeomagnetism}

\subsection{Previous palaeomagnetic studies}

In this paper we are primarily concerned with the history of motion of fragments in the Sorong Fault system where there have been no previous palaeomagnetic studies. A summary of the investigations of the areas adjacent to the fault system (Australian continental margin in northern New Guinea, the western end of the Sorong Fault Zone in east Sulawesi, and the Philippine Sea Plate) is presented below.

Studies in the Bird's Head region of New Guinea (Giddings et al., 1984, 1988, 1993) have reported clockwise rotations of the region between the Carboniferous and the Late Cretaceous-Middle Eocene, followed by a small counter-clockwise rotation between the Middle Miocene to the present. Giddings et al. have suggested that the Bird's Head has not moved any significant distance relative to the Australian Craton during the Phanerozoic. Data from Misool Island provide constraints on the motion of the Bird's Head region, as this area has probably been linked tectonically to the Bird's Head area since at least the late Mesozoic. Thrupp et al. (1987) reported a result from the Turonian-Santonian Waaf Formation. However, their interpretation of this result was inconclusive because the age of the magnetisation was uncertain; if the magnetisation is primary, the result indicates a post-Santonian counterclockwise rotation of $33^{\circ}$, but it could also be the result of an early Tertiary remagnetisation. Thrupp et al. considered there to have been no discernible motion between Misool and the Australia Plate after the magnetisation had been acquired. Wensink et al.
(1989) reported remanence data from two Upper Cretaceous formations on Misool. Results from the Waaf Formation indicate a $\sim 40^{\circ}$ counter-clockwise rotation whereas results from the Maastrichtian Fafanlap Formation indicate negligible rotation. Wensink et al. suggested that there may have been as much as $1000 \mathrm{~km}$ of relative motion between Misool and the Australian Plate during the Tertiary.

Data from the east arm of Sulawesi have recently been presented by Mubroto et al. (1994). Lower Cretaceous cherts and Upper Cretaceous-lower Tertiary basalts indicate formation palaeolatitudes of $\sim 20^{\circ} \mathrm{S}$. However, interpretations of declinations are less certain as both clockwise and counter-clockwise rotations are indicated which may reflect local fault tectonics.

Palaeomagnetic data from the Philippine Sea Plate are also of relevance since Halmahera, Waigeo and smaller surrounding islands form part of the plate. Evidence for northward movement of about $15-20^{\circ}$ of the Philippine Sea Plate has been widely accepted (see review by Haston and Fuller, 1991) but the suggestions of major rotation of the plate have proved more controversial. Interpretations of major (50$100^{\circ}$ ) clockwise rotations of the entire plate have been based on the magnetic anomaly skewness in the West Philippine Basin (Louden, 1977; Shih, 1980) and palaeomagnetic data from the eastern margin of the plate (Kodama et al., 1983; Haston and Fuller, 1991; Koyama et al., 1992) but have been disputed for a number of reasons. These include the low resolution provided by anomaly skewness studies, conflict with interpretations based on Shikoku Basin seamount data (Vaquier and Uyeda, 1967) and possibility of local tectonic effects due to subduction at the eastern plate edge (Larson et al., 1975; McCabe and Uyeda, 1983). The first palaeomagnetic data from the southern part of the Philippine Sea Plate were obtained from the area immediately north of the Sorong Fault system (Hall et al., 1995a, b-this issue). These new data indicate large clockwise rotations of the whole plate and can be used to determine the history of motion of the plate in the interval 0-50 Ma. Reconstructions based on these data provide a framework for interpreting results presented in this paper from within the Sorong Fault Zone and the development of the Australia-Philippine Sea plate boundary. 

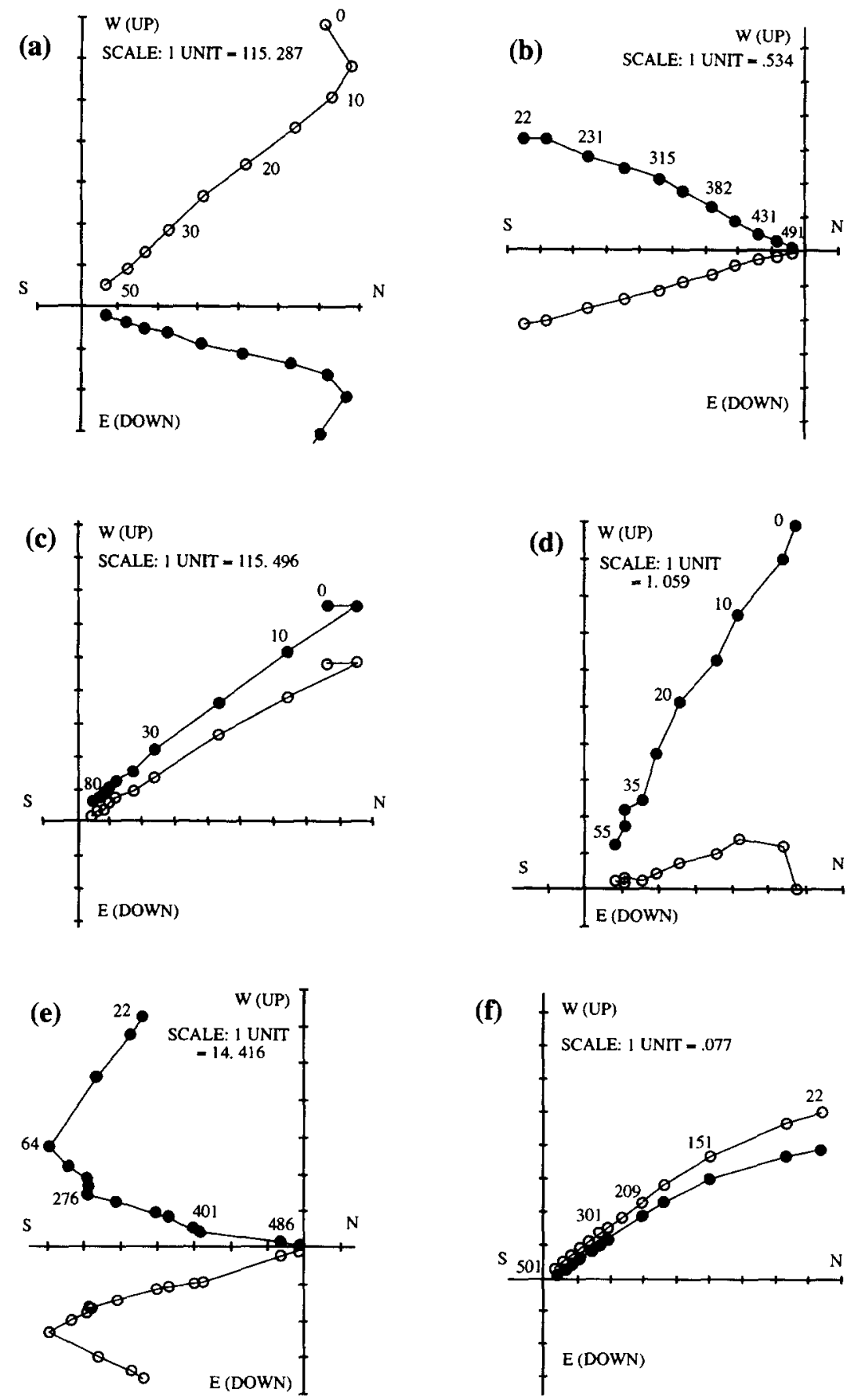

Fig. 4. Representative demagnetisation vector endpoint plots for material sampled from Obi. AF = alternating field demagnetisation (values in the range 0 to $50-80 \mathrm{mT}$ ); $\mathrm{TD}=$ thermal demagnetisation (values in the range $20-550^{\circ} \mathrm{C}$ ). Woi Formation (a) lavas (AF) and (b) sediments (TD) at Bobo waterfall; (c) Woi Formation lavas (AF) in the Sesepe River; (d) turbidites of the Anggai River Formation (AF) in the Anggai River; (e) Leleobasso Formation (TD), Tanjung Leleobasso. A TD plot (f) is shown for the Tanamu Formation, Taliabu. - remanence vector on the horizontal plane; $O=$ vector on a vertical plane. 


\subsection{Palaeomagnetic background}

In eastern Indonesia there are problems in collecting both palaeomagnetic and geological samples which are not typical of investigations elsewhere in the world. Although the field area is covered in primary rain forest, and rocks are exposed in only a small percentage of the area and often strongly affected by tropical weathering, many excellent exposures suitable for palaeomagnetic sampling can be found along the coast and in river valleys. Fieldwork requires carefully planned expeditions with a team of geologists working from a locally hired boat. Access for the field party is by smaller boat from which sorties are made either to coastal outcrops, or on foot to river valleys along which multi-day traverses are carried out with the aid of teams of local porters. For reasons of expedition safety and overall logistics the number of sites that can be drilled is often limited, and constrained by both the sizes of the exposures and time. It is often not possible to drill 6-12 sites at each locality or river section as may be the case in a palaeomagnetic investigation of a more accessible region. Most sampling sites were located to $\pm 30 \mathrm{~m}$ using a Magellan Navpro 1000 GPS receiver. The ages for all the formations reported in this study are based on new $\mathrm{K}-\mathrm{Ar}$ isotopic, nannoplankton and foraminiferal dating. Biostratigraphic determinations have been converted to numerical ages using the scheme of Harland et al. (1990).

\subsection{Palaeomagnetic methods}

At each site $25 \mathrm{~mm}$ cores were obtained using a gasoline powered rock-drill and oriented to $\pm 2^{\circ}$ using a magnetic compass-inclinometer. The magnetic stability of each specimen was assessed using either stepwise alternating field demagnetisation or continuous thermal demagnetisation (Dunn and Fuller, 1984). Demagnetisation data were analysed using equal area and Zijderveld (1967) plots (e.g. Fig. 4) from which characteristic components of remanence for each specimen were determined. Site mean directions were computed using the statistics of Fisher (1953). The statistical methods of McElhinny (1964) and McFadden (1990) have been used to constrain the age of magnetisation relative to the
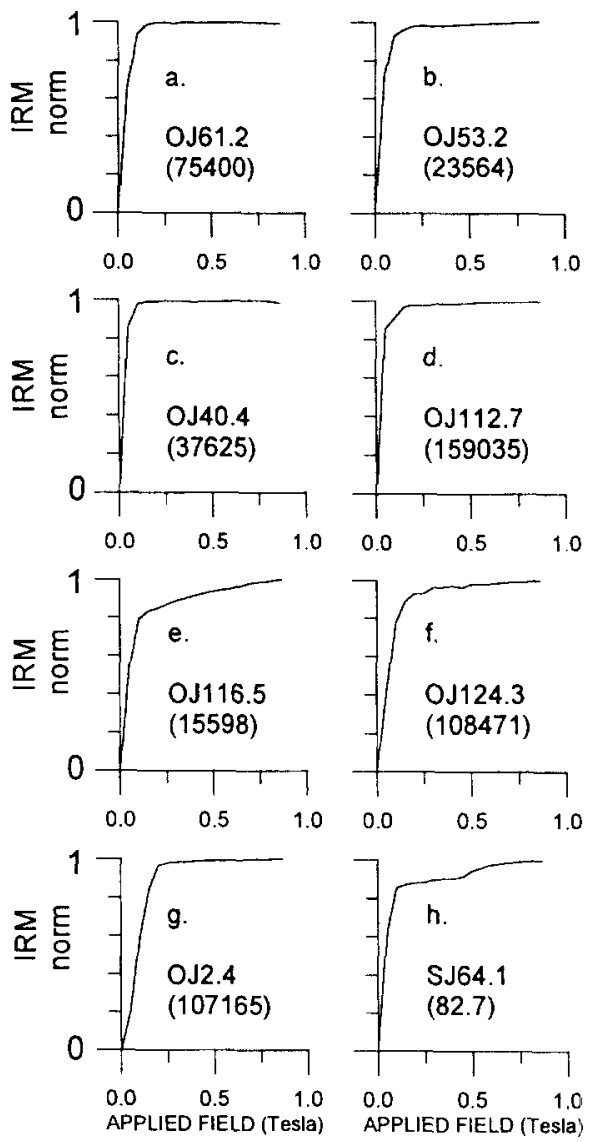

Fig. 5. IRM acquisition curves for representative material from Obi. IRM are normalised to the peak value (shown in parentheses, and expressed in $\mathrm{mAm}^{2}$ ). Woi Formation (a) lavas and (b) sediments at Bobo waterfall; (c) Woi Formation lavas from the Sesepe River; (d) and (e) turbidites of the Anggai River Formation in the Anggai River; (f) Leleobasso Formation, Tanjung Leleobasso. IRM curves for material from ( $\mathrm{g}$ ) the Tanamu. Formation near Tanamu, Taliabu.

folding episodes affecting a number of drilled sequences.

In addition, isothermal remanent magnetisation (IRM) analyses were carried out on representative specimens from each of the formations yielding reliable data to determine their principal remanence carriers (Fig. 5). Specimens were progressively magnetised using a Molspin pulse magnetiser, to peak direct fields of $0.86 \mathrm{~T}$. The IRM was measured between steps using a Molspin spinner magnetometer. The shape of the IRM acquisition curve, together with observations of the behaviour of the specimens subjected to thermal demagnetisation, were used to 
determine the characteristic remanence carrier(s). The IRM ratio, defined by Ali (1989), is the ratio of the IRM at $0.3 \mathrm{~T}$ to the IRM at $0.86 \mathrm{~T}$. As a general guide, values above 0.9 indicate magnetite is the dominant remanence carrier, whereas values below 0.9 indicate that the remanence may be due to other minerals.

As well as the standard directional and magnetomineralogical studies, the NRM:IRM demagnetisation technique, developed by Fuller et al. (1988), has been applied to two extrusive units for which reliable directional data have been obtained. Their method, based on empirical observations, is used to help determine whether an igneous body has a primary thermoremanent magnetisation (TRM), or secondary chemical remanent magnetisation (CRM). In this test, the decay of the specimen's NRM intensity during AF demagnetisation is compared with the decay of the specimen's saturation IRM at equivalent fields. According to Fuller et al., if the NRM:IRM for most of the demagnetisation steps is of the order of $10^{-2}$, or greater, then the NRM is likely to be a TRM. However, when the ratio is of the order of $10^{-3}$ or less, the remanence probably results from a CRM.

\section{Palaeomagnetic results: Obi Island}

A total of 65 drilled sites and 8 oriented specimens were obtained from Mesozoic and Cenozoic rocks on Obi during fieldwork for the Sorong Fault Zone Project (Fig. 2). Reliable palaeomagnetic results have been obtained from three formations exposed in northern and southern Obi. The palaeomagnetic site mean data are summarised in Tables 1-3 and Figs. 6-9.

\subsection{Bobo waterfall section: Woi Formation}

The Upper Miocene Woi Formation was sampled in a waterfall section approximately $12 \mathrm{~km} \mathrm{NNW}$ of Bobo, south Obi. The basal part of the section exposes an unknown thickness of brecciated volcanic rocks. These are conformably overlain by a $\sim 10 \mathrm{~m}$ thick shallow-marine clastic sequence, which in turn is conformably overlain by about $12 \mathrm{~m}$ of andesitic

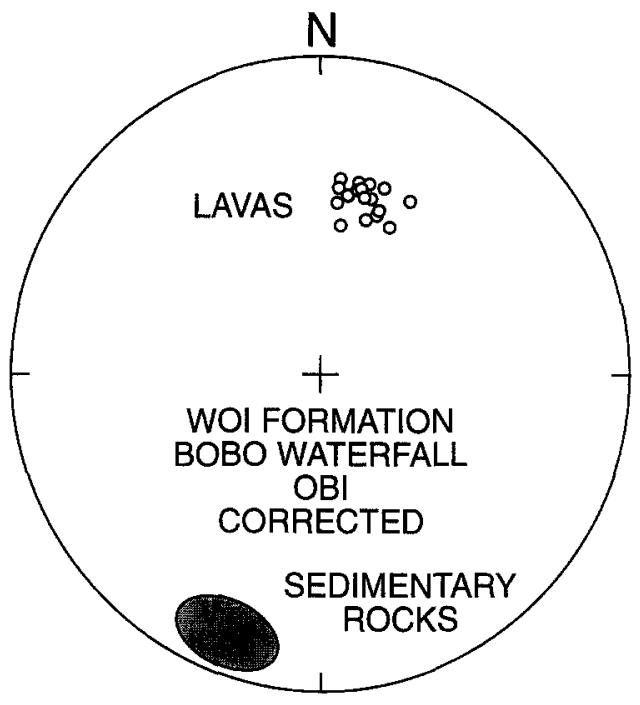

Fig. 6. Equal-area stereographic projection of the tilt-corrected directional data from the Upper Miocene Woi Formation near Bobo, south Obi. $O=$ upward dipping specimen directions obtained from the lavas. The mean direction for Site OJ53 (drilled in the underlying sandstone succession) is downward dipping and shown with its $95 \%$ confidence circle.

lavas. The whole sequence dips gently to the NW at about $3^{\circ}$.

For the most part the lavas are inaccessible in the steep waterfall, and only the upper $3 \mathrm{~m}$ of the section could be drilled. IRM analysis of two of these specimens showed IRM ratios of 1.0, indicating magnetite as their principal remanence carrier (Fig. 5a). Thermal demagnetisation of 4 specimens revealed unblocking temperatures in the range $510-560^{\circ} \mathrm{C}$, supporting the deduction from the IRM behaviour. NRM:IRM demagnetisations performed on three representative specimens from the lavas have ratios typically $2-5 \times 10^{-2}$, suggesting that their remanence is a TRM. Although four horizons were collected from these lavas, the specimens are grouped as a single site, because of their close spacing, with an in-situ mean direction of $D=11.9^{\circ}, I=-41.3^{\circ}$, $N=18, \alpha_{95}=2.9^{\circ}, K=154$ (Table 1). The tilt-corrected mean direction is $D=14.8^{\circ}, I=-41.8^{\circ}$ (Fig. 6).

The underlying sedimentary succession was drilled at 6 sites. Only one of the six sites produced a reliable result with a mean in-situ direction of $D=$ $199.7^{\circ}, I=13.3^{\circ}, N=7, \alpha_{95}=10.8^{\circ}, K=32$, and a tilt-corrected mean direction of $D=200.4^{\circ}, I=13.8$ 


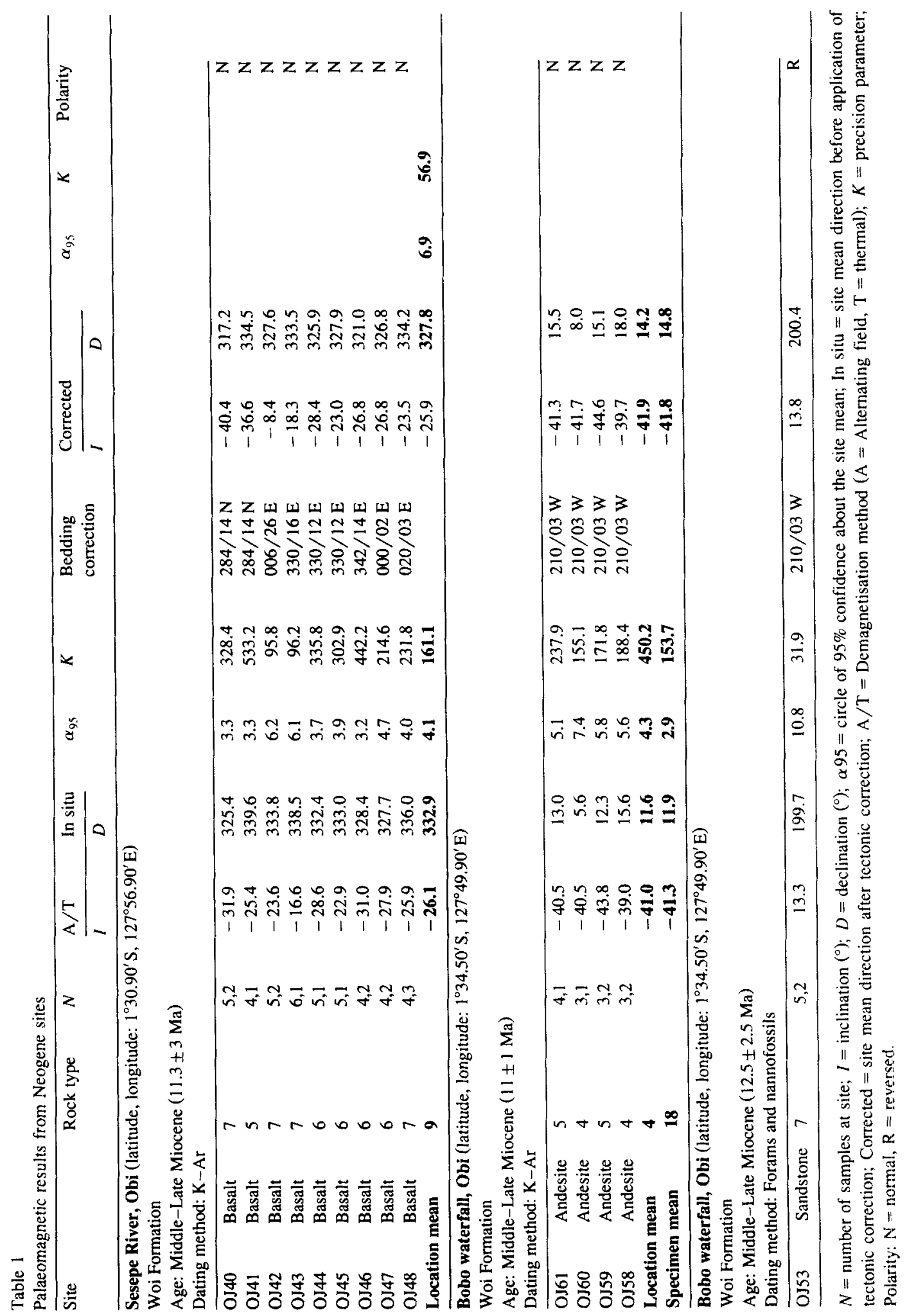


(Fig. 6). IRM analysis of two specimens from this site showed IRM ratios of 0.98 and 0.99 , indicating magnetite as the dominant remanence carrier (Fig. $5 b)$.

The Bobo waterfall section has yielded reliable palaeomagnetic directions which are almost certainly primary because both normal and reverse magnetised sites have been identified. NRM:IRM demagnetisation experiments indicate that the remanence of the lavas is primary. The results from the lavas are interpreted as indicating normal polarity magnetisation with clockwise rotation of $\sim 15^{\circ}$ (with respect to the present-day dipole field direction). They record an inclination of $-42^{\circ}$, implying a formation latitude of $24^{\circ} \mathrm{S}$ which is unusually high for a Upper Miocene formation now situated at $1.5^{\circ} \mathrm{S}$. It is likely that the effects of geomagnetic secular variation have not been fully averaged-out for the lavas. The sedimentary rocks have a reverse polarity remanence suggesting about $20^{\circ}$ of clockwise rotation. Their inclination of $14^{\circ}$ implies a formation latitude of $7 \pm 6^{\circ} \mathrm{S}$.

\subsection{Sesepe River: Woi Formation}

Andesitic lava flows up to two metres thick assigned to the Upper Miocene Woi Formation were drilled at nine sites in a $1 \mathrm{~km}$ river section located approximately $7 \mathrm{~km}$ to the south of Kelo, east Obi.
Individual lava flows exhibit both subvertical jointing and an internal planar fabric with locally variable dips of up to $16^{\circ}$ towards the NE which are parallel to the attitude of the flows. It was not possible to be certain whether these surfaces represent a palaeohorizontal since there are no sedimentary rocks in the Sesepe River sequence. The regional dip of the Woi Formation in this area is similar and is no more than $10-20^{\circ}$ towards the NE.

IRM analysis of two specimens from this sequence showed IRM ratios of 1.0, suggesting that the magnetisation is carried by magnetite (Fig. 4c). Thermal demagnetisation of 15 specimens demonstrated unblocking temperatures of between 510 and $540^{\circ} \mathrm{C}$ typical of magnetite. NRM:IRM demagnetisation experiments were performed on four representative specimens and in all cases, the NRM:IRM demagnetisation ratio is greater than $10^{-2}$ for AF of 10 $\mathrm{mT}$ or above, suggesting that the NRM is a TRM.

Demagnetisation isolates an essentially single component remanence and all nine sites drilled at this locality yielded reliable palaeomagnetic directions. The in-situ mean direction of $D=332.9^{\circ}$, $I=-26.1^{\circ}, \alpha_{95}=4.1^{\circ}, K=161$ (Table 1, Fig. 7) After the individual site tilt (flow attitude) corrections have been applied $D=327.8^{\circ}, I=-25.9^{\circ}$, $\alpha_{95}=6.9^{\circ}, K=57$.

The NRM:IRM experiments indicate that the

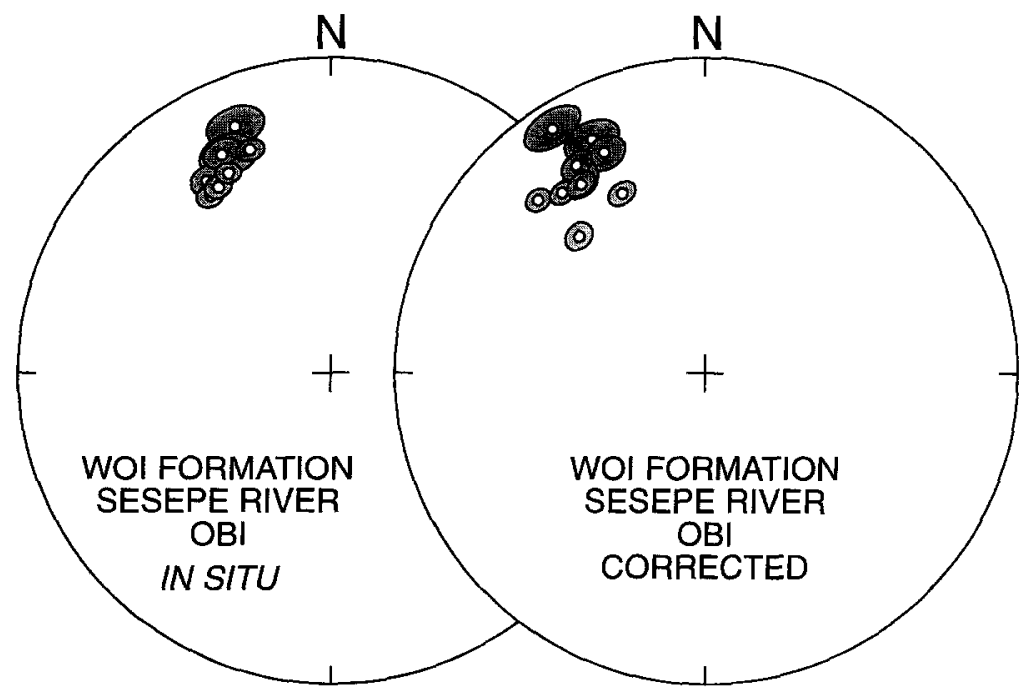

Fig. 7. Equal-area stereographic projection of the in-situ and tilt-corrected site mean directions for the Upper Miocene Woi Formation lavas in the Sesepe River, east Obi. All site vectors are upward dipping and shown with their $95 \%$ confidence circle. 
magnetisation of this unit is primary. The higher $K$ value of the mean in-situ direction suggests that the flow fabric represents a depositional rather than palaeo-horizontal surface. The rocks have a normal polarity magnetisation, which is rotated counterclockwise by $27^{\circ}$, and their inclination angle of $-26.1^{\circ}$ suggests a formation latitude of $14 \pm 4^{\circ} \mathrm{S}$.

\subsection{Anggai River: Anggai River Formation}

Eleven sites were sampled at three sections, about $1 \mathrm{~km}$ apart, in the Upper Oligocene Anggai River Formation exposed in the Anggai River of north Obi. The rocks drilled in these sections include subordinate breccio-conglomerates and hard well-indurated calcareous volcaniclastic sandstones, siltstones and mudstones. These lithologies are regularly interbedded; sandstones are up a few metres in thickness and the finer grained rocks are typically $30-80 \mathrm{~cm}$ thick. There is a variety of sedimentary structures indicating the rocks are turbidites. The strike and dip is similar in each section and the beds dip towards the $\mathrm{NE}$ at $\sim 60^{\circ}$.

Specimens from the stratigraphically youngest and oldest sections have IRM ratios of 0.98 and 0.96 , respectively, indicating magnetite as the principal remanence carrier (Fig. 5d). Specimens from the middle section have IRM ratios of 0.89 and 0.90 suggesting that another ferromagnetic mineral in addition to magnetite is present (Fig. 5e). Thermal demagnetisation of specimens from the middle section indicate that most of the NRM is removed below the Curie Point for magnetite, but that about $1-4 \%$ of the NRM remains at temperatures around $600^{\circ} \mathrm{C}$. This suggests that both magnetite and hematite are present in these rocks.

All eleven sites have yielded reliable magnetisations. Both thermal and AF demagnetisation suggest that the remanence records a single direction indicating that the haematite component of magnetisation, where present, is parallel to the magnetite component. The in-situ mean direction is $D=332.4^{\circ}, I=$ $-21.5^{\circ}, N=11, \alpha_{95}=8.2^{\circ}, K=32$ (Table 2) The mean of the tilt-corrected site directions is $D=$ $301.1^{\circ}, \quad I=-23.6^{\circ}, \alpha_{95}=8.8^{\circ}, K=28$ (Fig. 8). The rocks carry a normal polarity magnetisation which is deflected counter-clockwise through almost

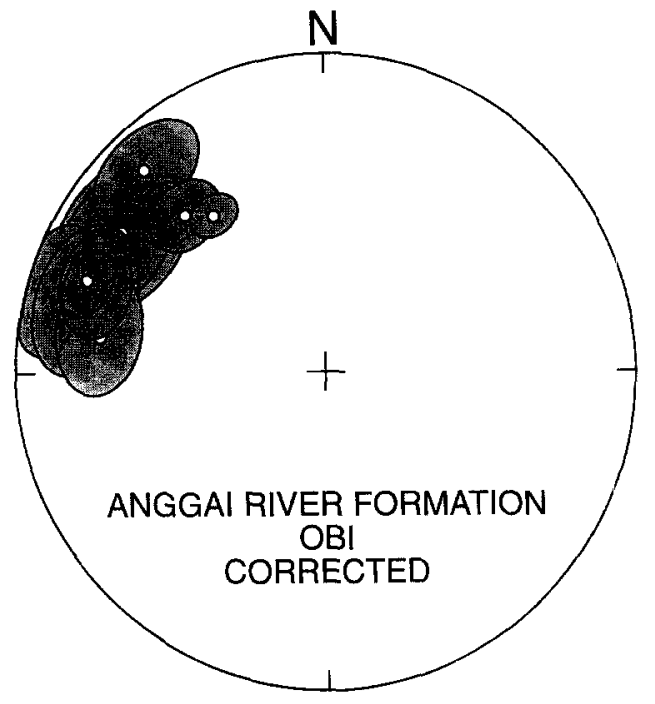

Fig. 8. Equal-area stereographic projection of the tilt-corrected site mean directions for the Upper Oligocene Anggai River Formation near Anggai, north Obi. All of the site vectors are upward dipping and shown with their $95 \%$ confidence circle.

$60^{\circ}$. The inclination value implies that the rocks formed at $12 \pm 6^{\circ} \mathrm{S}$.

\subsection{Tanjung Leleobasso: Leleobasso Formation}

The Upper Cretaceous Leleobasso Formation was sampled at the southern end of the type locality at three sites drilled in a coastal section about $2 \mathrm{~km}$ long. In this section there are well bedded green volcaniclastic conglomerates, sandstones and mudstones which are turbidites and debris flow units. All the rocks are the right-way up and dip $\sim 20^{\circ}$ to the ESE. In this area the rocks are very hard and splintery where they are close to the contact of a hornblende diorite intrusion. At the north end of the section is the unexposed contact between diorite and sedimentary rocks. The mudstones drilled have been partially recrystallised at low metamorphic grade (sub-greenschist facies).

IRM analysis of two representative specimens showed IRM ratios of 0.98 indicating that magnetite is the remanence carrier (Fig. 5f). This deduction is supported by thermal demagnetisation which indicates unblocking temperatures of between 540 and $565^{\circ} \mathrm{C}$. Both thermal and $\mathrm{AF}$ demagnetisation reveals an essentially single component remanence (Fig. 4e) The directions obtained from these sediments are 


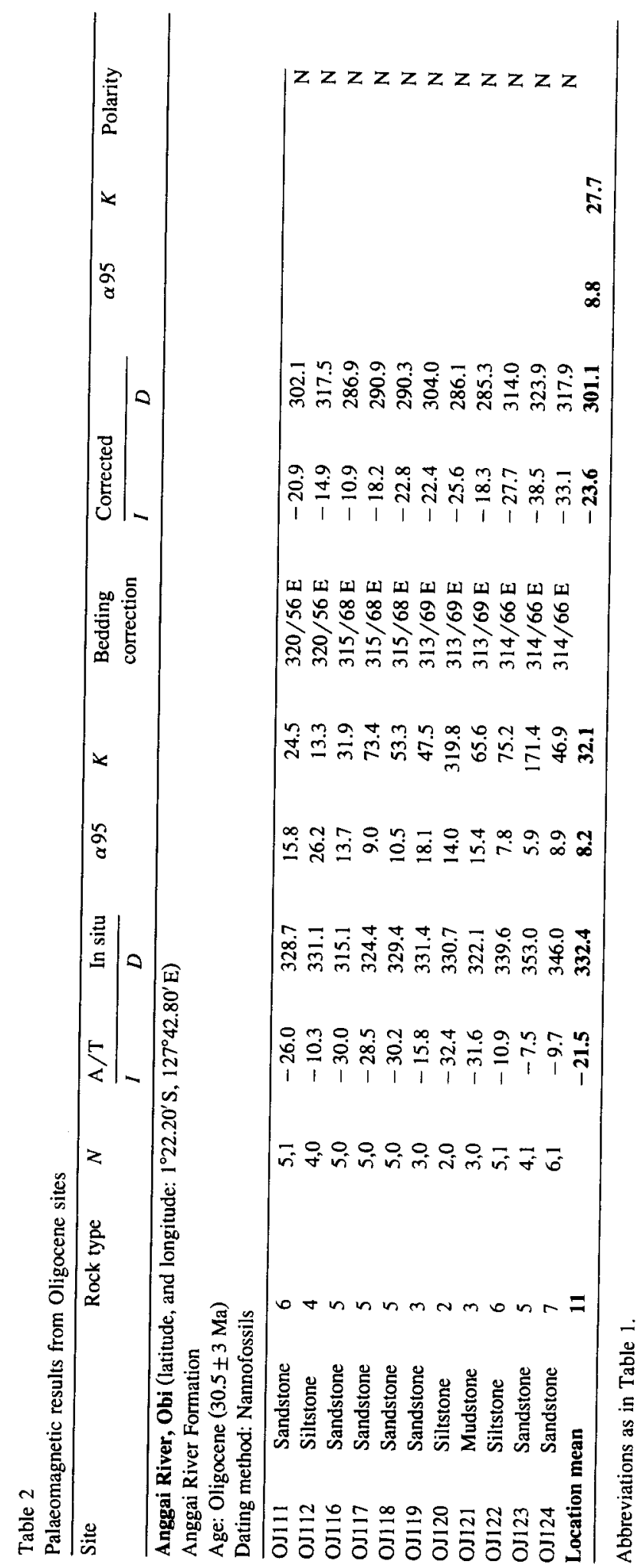




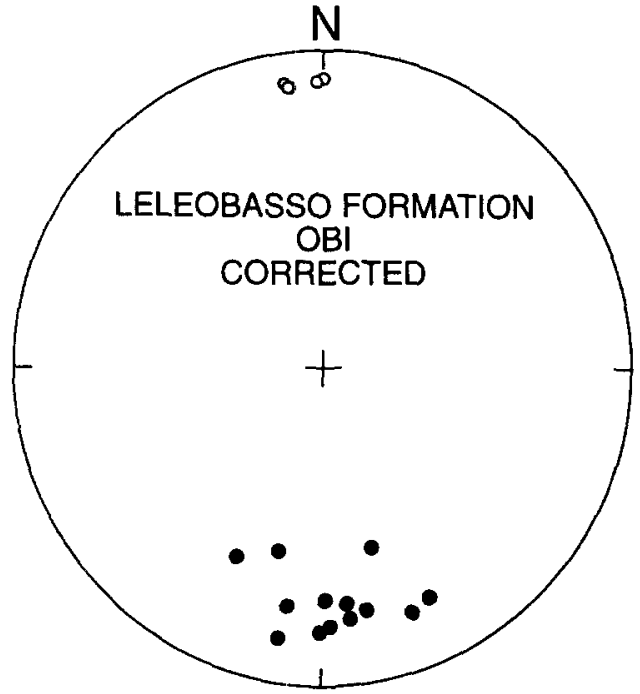

Fig. 9. Equal-area stereographic projection of the tilt-corrected specimen directions for the Upper Cretaceous Leleobasso Formation near Tanjung Leleobasso, northwest Obi. $=$ downward dipping vectors; $\mathrm{O}=$ upward dipping vectors. considered primary as two sites carry a reverse polarity magnetisation whereas the third carries a normal polarity. In addition the latter site includes six specimens from one bed with normal polarities and one specimen from an adjacent, but not stratigraphically equivalent, level with a reverse polarity. As the rocks were sampled at just three sites, the in-situ mean direction has been calculated using the data from the individual specimens yielding $D=5.5^{\circ}, l=-27.8^{\circ}$, $N=18, \alpha_{95}=6.4^{\circ}, K=30$ (Table 3 ). The tillt-corrected specimen mean direction is $D=357.1^{\circ}, I=$ $-21.9^{\circ}$ (Fig. 9). Grouping the tilt-corrected directions at site level produces a mean of $D=355.5$, $I=-22.1, \alpha_{95}=19.8^{\circ}, K=40$. If the magnetisation is assumed to be a normal polarity remanence then the rocks formed at $11 \pm 4^{\circ} \mathrm{S}$ and have undergone negligible net rotation. Alternatively, if the remanence is considered to be a reverse polarity magnetisation the rocks must have formed at $11 \pm$ $4^{\circ} \mathrm{N}$ and have since undergone $\sim 180^{\circ}$ net rotation.

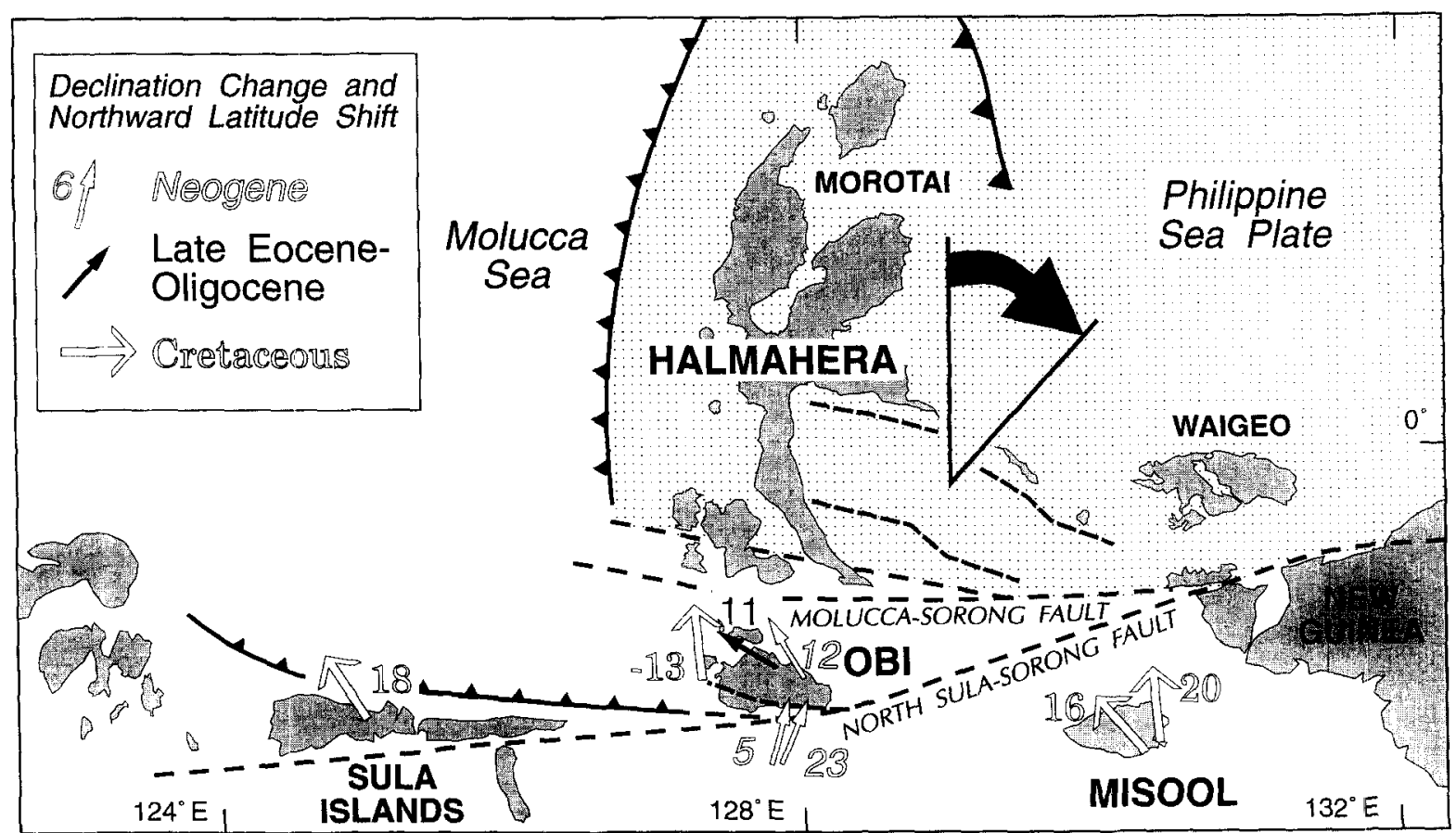

Fig. 10. Summary of the palaeomagnetic data obtained during the Sorong Fault Zone project reported in this paper. The orientations of the arrows indicate the declination offsets. Numbers next to each arrow indicate the apparent northward latinude shift. Also included are two Late Cretaceous directions from Misool (Wensink et al., 1989). The shaded area north of the Sorong Fault Zone currently forms part of the Philippine Sea Plate and has rotated clockwise by approximately $90^{\circ}$ since the Early Eocene (Hall et al., 1995a, b-this issue). 


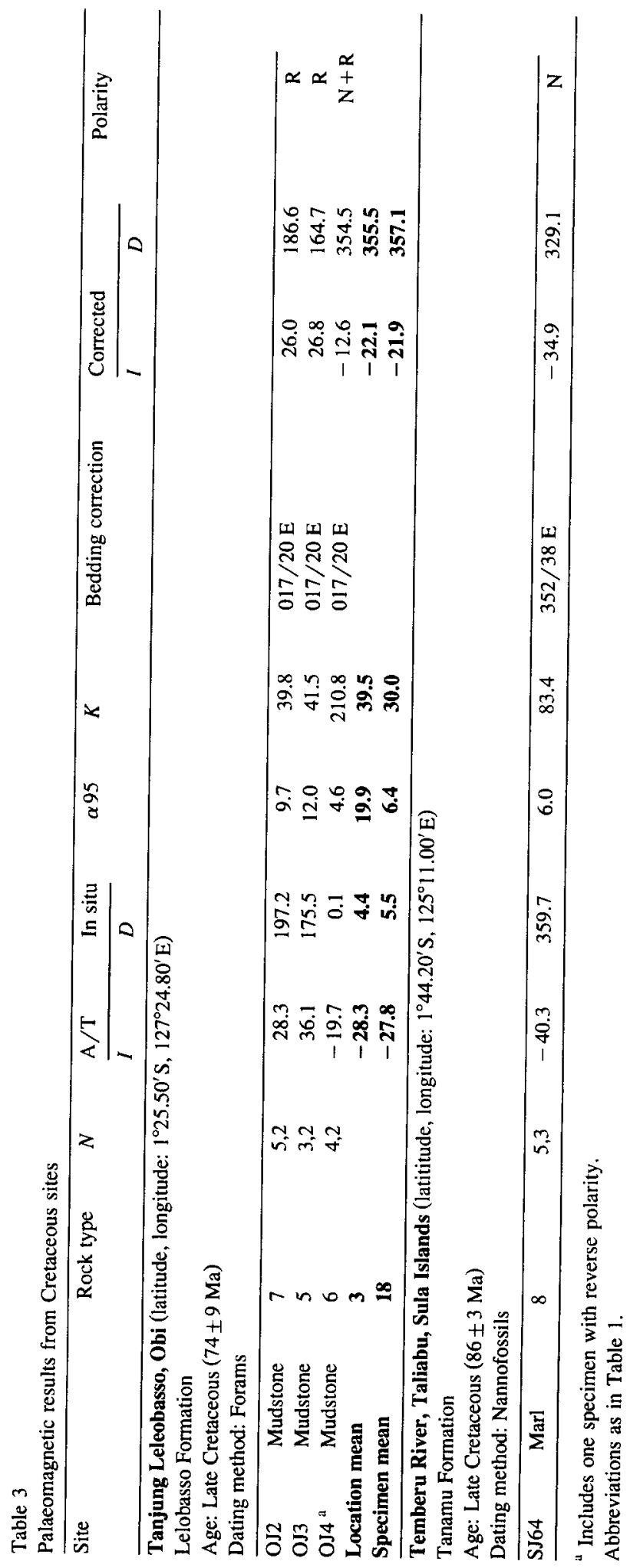




\section{Palaeomagnetic results: Sula Islands}

\subsection{Taliabu: Tanamu Formation}

A total of 44 sites were collected in the Banggai-Sula Islands and on the east arm of Sulawesi. Of these, only a single site collected from the Upper Cretaceous Tanamu Formation has yielded a measurable primary magnetisation. Eight cores were sampled from a $\sim 50 \mathrm{~cm}$ interval in a section exposed in the Temberu River, Taliabu, close to the type locality of the formation. The rocks are thinly bedded white calcilutites and marls, with subordinate horizons of black mudstones and shales, which dip to the NE at $\sim 20-40^{\circ}$; they have been dated as Coniacian-Santonian using nannofossils.

IRM ratios for two specimens were 0.89 and 0.90 suggesting that the remanence is carried by high coercivity component (Fig. 5g). However, thermal demagnetisation is complete by about $530^{\circ} \mathrm{C}$ implying the remanence is carried by magnetite. The in-situ site mean direction is $D=359.7^{\circ}, I=$ $-40.3^{\circ}, N=8, \alpha_{95}=6.0^{\circ}, K=83$ (Table 3). The tilt-corrected mean direction is $D=329.1^{\circ}, \quad I=$ $-34.9^{\circ}$. The remanence direction suggests a counter-clockwise rotation of $\sim 30^{\circ}$ and a formation latitude of $19 \pm 5^{\circ} \mathrm{S}$.

\section{Interpretation: the Sorong Fault Zone}

Palaeomagnetic data collected from rocks of Philippine Sea Plate origin (Fig. 10) during this project define two principal areas with different tectonic histories: an area north of the Sorong Fault and an area within the Sorong Fault Zone.

\subsection{Inclination data and latitudinal movements}

All Cretaceous and Tertiary rocks of Philippine Sea Plate origin in the Sorong Fault Zone have shallow inclinations and formed at low latitudes. Three localities, all drilled in Upper Miocene lavas, yield anomalous steep inclinations suggesting that the effects of secular variation have not been averaged out, although all three localities record northward translations with decreasing age. The inclinations recorded by the Obi sites suggest that Obi and the area north of the Sorong Fault system (Hall et al., 1995a, b-this issue) have effectively the same northward motion history during the Neogene (Fig. 11).

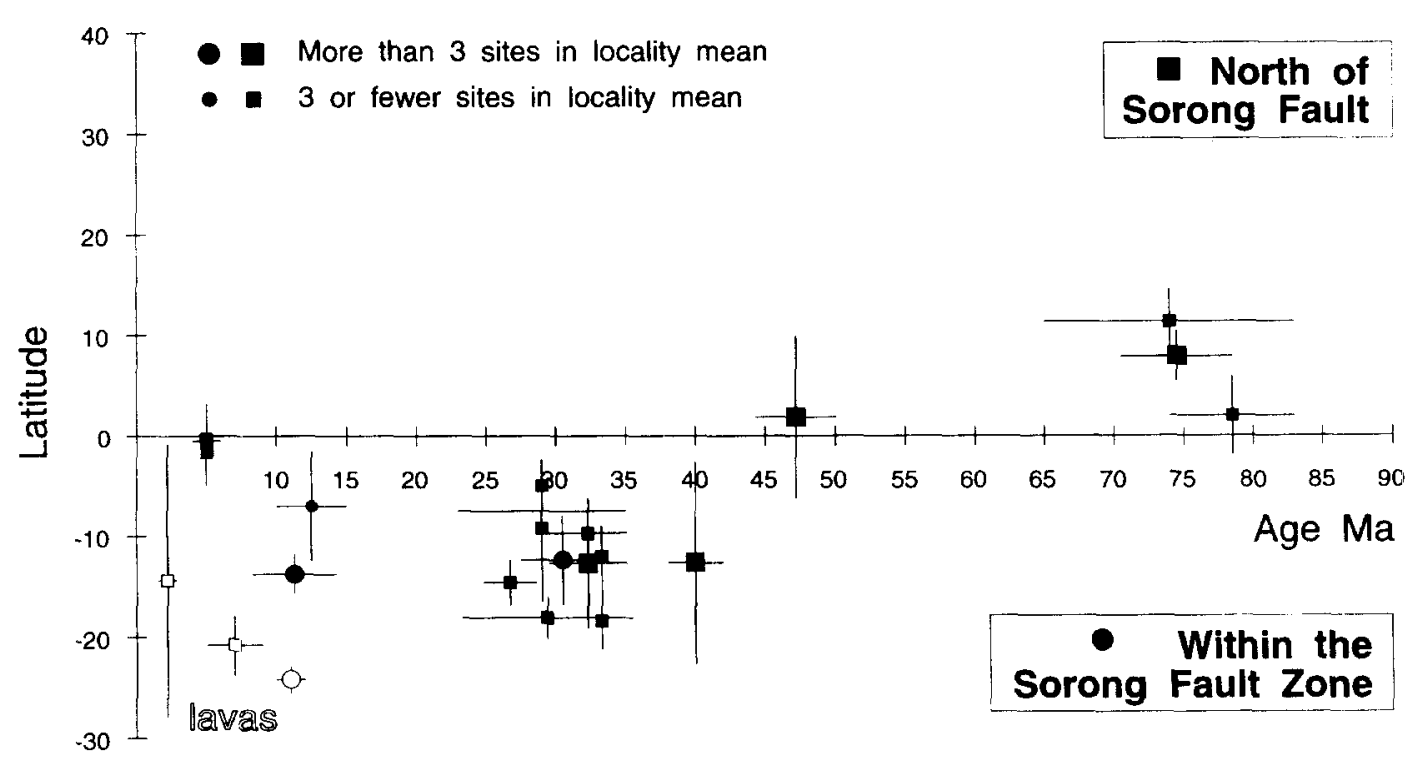

Fig. 11. Latitude vs. age plot for Philippine Sea Plate rocks north of and within the Sorong Fault Zone. Positive latitudes are northern hemisphere. Some lavas record higher inclinations than associated sedimentary rocks; this is attributed to sampling of lava sequences enupted in a short time span, thus failing to fully average out secular variation in the geomagnetic field. 
The results indicate about $10^{\circ}$ of northward translation since the Early Miocene. This is similar to estimates from palaeomagnetic studies elsewhere in the Philippine Sea Plate (Louden, 1977; Keating and Herrero, 1980; Kinoshita, 1980; Bleil, 1981; Kodama et al., 1983; Hirooka et al., 1985; Haston and Fuller, 1991; Haston et al., 1992; Koyama et al., 1992).

Low Cretaceous palaeolatitudes for the southern part of the Philippine Sea Plate are consistent with the lithological character of the Cretaceous sequences (Hall et al., 1988a). The interpretation of their exact site of magnetisation depends upon the inferred rotation history. Counter-clockwise rotation between the Late Cretaceous and Early Miocene implies a Northern Hemisphere origin and reversed polarity for the Cretaceous magnetisation. A clockwise rotation implies a Southern Hemisphere origin and normal polarity.

\subsection{Declination data and rotations}

The West Philippine Basin is the oldest part of the Philippine Sea Plate (Hilde and Lee, 1984) and the islands of Halmahera, Bacan, Obi and Waigeo form the southern edge of the basin. The islands in the area north of the Sorong Fault include the oldest rocks within the Philippine Sea Plate and provide a record of Philiipine Sea Plate motion which can be used as a reference to distinguish local rotations within the Sorong Fault Zone. Hall et al. (1995a, b-this issue) have shown that the very large area north of the Sorong Fault system has a distinctive and consistent rotation history. There was approximately $40^{\circ}$ of clockwise rotation after $\sim 25 \mathrm{Ma}$ at an approximately constant rate, no significant rotation between $\sim 25$ and $\sim 40 \mathrm{Ma}$, approximately $45^{\circ}$ of clockwise rotation between $\sim 40$ and $\sim 50 \mathrm{Ma}$, and $\sim 90^{\circ}$ rotation between the Late Cretaceous and the Early Eocene.

In contrast to the area north of the Sorong Fault system, in north Obi Tertiary rocks record counterclockwise rotations increasing with age whereas the south Obi sites record small clockwise rotations (Figs. 10 and 11). Sites in north and south Obi drilled in the Woi Formation are of almost identical ages yet record quite different declinations. Geological mapping based on aerial photographs and fieldwork shows that these two groups of sites are separated by a major post-Miocene WNW-ESE fault similar in orientation to Pliocene splays of the Sorong Fault system further north. Seismic lines (Hamilton, 1979; Letouzey et al., 1983) and GLORIA data (Masson et al., 1988) show that Obi is separated from the islands further north by a major submarine fault strand, the Molucca-Sorong Fault, and is bounded on its southern side by the North Sula-Sorong Fault. We therefore consider it most likely that the differences in rotation history between parts of Obi and the Philippine Sea Plate to the north are attributable to movements within the Sorong Fault system.

\subsection{Age and initiation of the Sorong Fault system}

A very important implication of the geological and palaeomagnetic work carried out during this project (Hall et al., 1995a, b-this issue) has been an understanding of when the Sorong Fault was initiated. Between $\sim 40$ and $25 \mathrm{Ma}$ the Philippine Sea Plate remained essentially static (Hall et al., 1995bthis issue); subduction of Indian Ocean lithosphere beneath its southern edge is recorded by Oligocene volcanic arc rocks in the Sorong Fault Zone. At $\sim 25 \mathrm{Ma}$ volcanic arc activity ceased and there is a major regional unconformity with Lower and Middle Miocene limestones above older rocks. We interpret the unconformity to mark the collision between the Philippine Sea Plate and the Australian margin (Fig. 2). At $\sim 25 \mathrm{Ma}$ the Philippine Sea Plate began rotating clockwise about a pole located near to $15^{\circ} \mathrm{N}$ and $160^{\circ} \mathrm{E}$. The computed poles of rotation for the Philippine Sea Plate indicate no significant convergence between the Philippine Sea Plate and Australia after $25 \mathrm{Ma}$, suggesting the existence of a strike-slip boundary (Hall et al., 1995a). The lack of convergence is also consistent with the absence of major Neogene volcanic activity in northern Irian Jaya (Pieters et al., 1983; Dow and Sukamto, 1984). The Philippine Sea Plate rotation pole probably shifted to its present-day position close to Japan during the Pliocene. The cause of this shift is incertain. There are a number of significant events in the western Pacific-Southeast Asian margin at this time which may be causes or effects: initiation of arc-arc collision between the Halmahera and Sangihe arcs, deformation in Halmahera related to fault movements on 
splays of the Sorong Fault, initiation of the Philippine Trench, arc-continent collision between the Luzon arc and the South China margin in Taiwan,

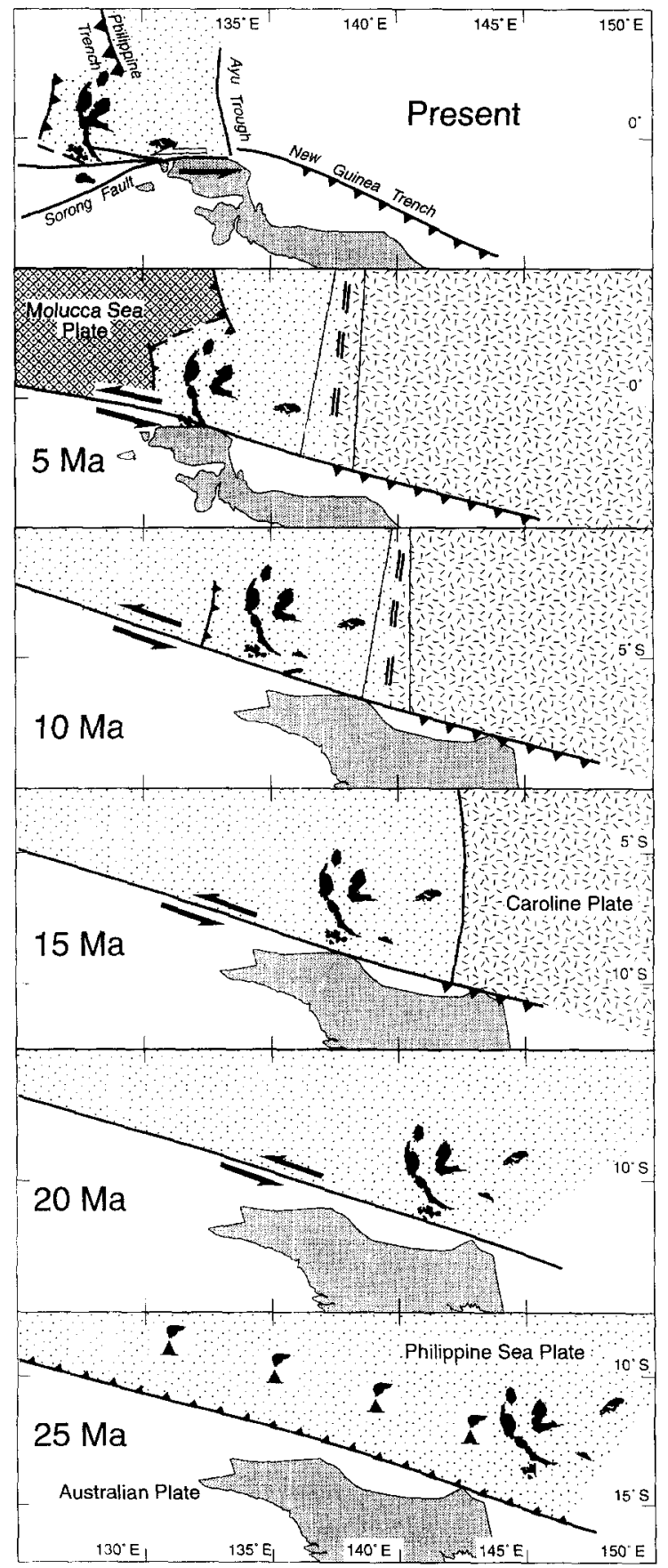

and collision between ophiolite and the Sula platform in east Sulawesi.

\subsection{Neogene displacements}

The area of south Bacan and Obi includes Philippine Sea Plate rocks thrust onto Australian continental basement during the $\sim 25$ Ma collision. Initiation of the Sorong Fault system caused remnants of continental crust to become attached to the Philippine Sea Plate and they have subsequently moved west at an average rate of $\sim 6 \mathrm{~cm} / \mathrm{yr}$, a rate comparable to estimates of movement along other major strike-slip faults (DeMets et al., 1990). Since $\sim 25 \mathrm{Ma}$ there has been left-lateral movement with $\sim 1500 \mathrm{~km}$ of displacement between the southern Philippine Sea Plate and the Australian Plate (Fig. 12), estimated from the reconstructions of Hall et al. (1995a, b-this issue). During the same time interval there has been rotation in both senses within the fault zone. Sites in north Obi indicate counter-clockwise rotations consistent with shear in a left-lateral fault system. There, the average rate of rotation is approximately twice and in the opposite sense to that of the driving plate, the Philippine Sea Plate, to the north.

\subsection{Regional implications}

East of the Bird's Head, geological knowledge of the Australian margin in New Guinea remains at a reconnaissance level because of the difficulty of the

Fig. 12. Development of the Sorong Fault system. Collision occurred at $\sim 25 \mathrm{Ma}$ between Australia and the volcanic arc along the southern edge of the Philippine Sea Plate. After collision the former subduction boundary between the two plates became a left-lateral strike-slip system (with negligible convergence between the two plates) as the Philippine Sea Plate began to rotate clockwise. As the Philippine Sea Plate rotated there would have been a non-convergent boundary with the plate(s) to the east. At present the Caroline Plate occupies this position and is converging with Australia; convergence is speculated to have begun during the Miocene. Arc fragments were detached and transferred to the Australian margin during the Miocene as strike-slip bounded terranes. At $\sim 12 \mathrm{Ma}$ subduction of the Molucca Sea Plate beneath Halmahera began. Ayu Trough spreading began in the Late Miocene. At $\sim 5$ Ma the Philippine Sea Plate rotation pole moved to its present location. Subduction began at the Philippine Trench and propagated south. 
region in terms of access, climate and physiography. However, there are many similarities between the stratigraphy of the Sorong Fault Zone and of the oceanic province (Dow, 1977; Pieters et al., 1983; Dow and Sukamto, 1984) in the New Guinea Orogen (Fig. 13). Important similarities include probable Mesozoic ophiolitic basement rocks of supra-subduction zone character; Eocene plutonic rocks, evidence of a Middle Eocene unconformity, Paleogene volcanic rocks, a major Upper Paleogene-Lower Miocene unconformity and Lower-Middle Miocene limestones.

The oceanic province has been subdivided by Pigram and Davies (1987) and Struckmeyer et al. (1993) into a number of terranes. The Arafak, Gauttier and Finisterre terranes all include Paleogene volcanic rocks overlain unconformably by LowerMiddle Miocene limestones and are those most similar to sequences of the Sorong Fault Zone which have a Philippine Sea origin. The Torricelli, Dimaie, Marum and Bowutu terranes also include Paleogene arc volcanic sequences. These terranes occupy the most northerly part of the New Guinea Orogen and are spread over a distance of about $1600 \mathrm{~km}$. They are typically elongate, aligned parallel to the orogenic belt and are separated by faults or sedimentary basins. Successor basins are Miocene and younger. Many of the long linear faults separating terranes have been suspected to have a strike-slip character but definite evidence is lacking in most cases (Bain, 1973; Pigram and Davies, 1987).

Pigram and Davies (1987) suggested that “... docking occurred because the Australian continent, which was moving northward, entered a subduction zone at which the terranes had assembled during the Paleogene ... by late Oligocene time'". A collision between the Australian margin and an island arc has been implied or explicitly suggested by many previous authors (e.g. Dow, 1977; Jaques and Robinson, 1977; Pieters et al., 1983; Pigram and Davies, 1987) although estimates of the age of this event vary. We suggest that this volcanic arc was situated at the southern edge of the Philippine Sea Plate during the Late Eocene-Oligocene and arc-continent collision occurred at $\sim 25 \mathrm{Ma}$. The composite character of some of the New Guinea terranes is consistent with the Mesozoic and Early Tertiary arc history of the Philippine Sea Plate recorded in the sequences of the

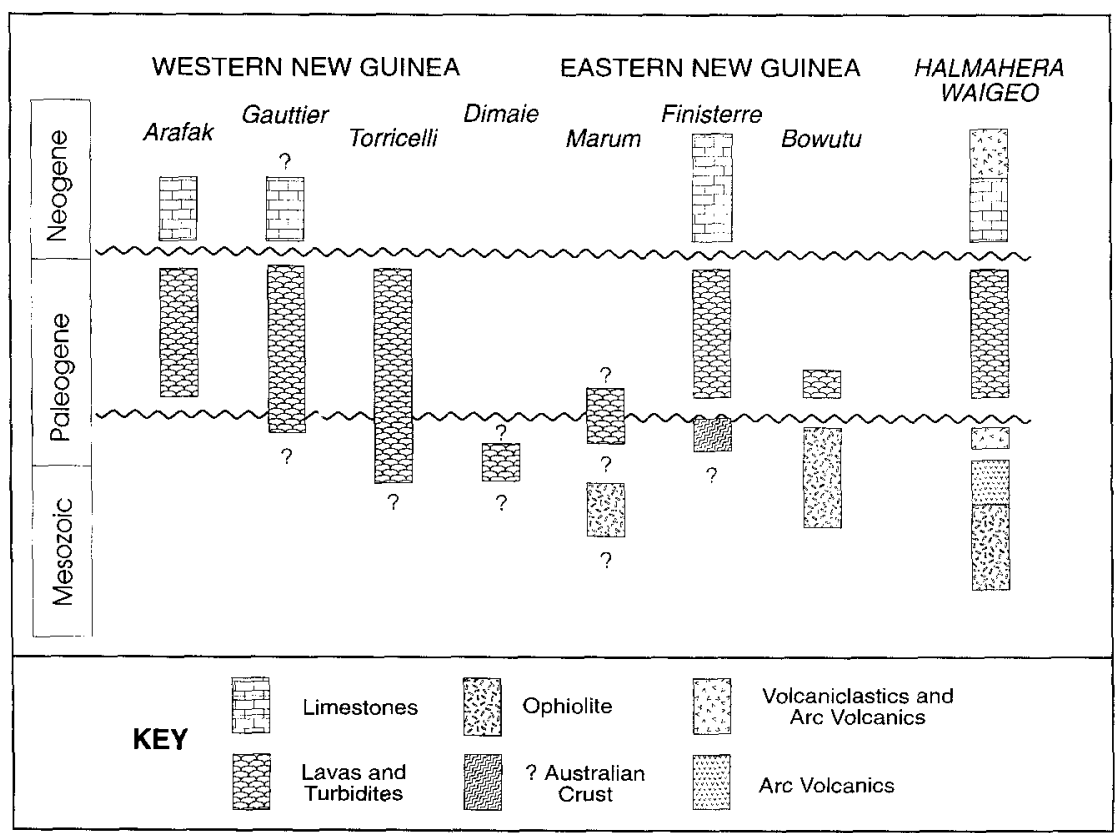

Fig. 13. Comparison of the principal features of the stratigraphy of New Guinea terranes (based on Pigram and Davies, 1987) and that of the southern Philippine Sea Plate based on our investigations of the Halmahera-Waigeo region. 
Sorong Fault Zone. We suggest that many of the supposedly separate New Guinea terranes are fragments of the Philippine Sea Plate arc later dismembered by strike-slip faulting as the plate moved westwards along the north Australian margin between $25 \mathrm{Ma}$ and the present (Fig. 12).

\section{Sula Platform}

\subsection{Origin of the Sula Platform}

The Sula Platform is a fragment of continental crust widely considered to have been transported west by the Sorong Fault. Its origin is uncertain. Many authors consider it to be a piece of New Guinea that was detached from western Irian Jaya in late Cenozoic time (e.g. Visser and Hermes, 1962; Hamilton, 1979; Silver and Smith, 1983) whereas Pigram et al. (1985) have proposed that it originated about $1000 \mathrm{~km}$ further east, in central Papua New Guinea. Suggestions for the site of origin of the Sula Platform have been based entirely on stratigraphic similarities discussed by Pigram et al. (1985). PrePermian low-grade metamorphic rocks are similar in Misool, the Bird's Head and central Papua New Guinea. Permo-Triassic granites and volcanics are present in both Sula and central Papua New Guinea but not in Misool and the Bird's Head. The Mesozoic stratigraphy of Sula is similar to Misool but different from central Papua New Guinea after the Jurassic. Pigram et al. (1985) suggested that these features indicate that the Sula Platform separated from a site in central Papua New Guinea before the Early Cretaceous.

Despite drilling 42 sites on the Sula Platform and east arm of Sulawesi we obtained a result from only one site. The formation latitude of $19 \pm 6^{\circ} \mathrm{S}$ for Coniacian-Santonian rocks indicated by the inclination data is closely similar to palaeolatitudes suggested for Upper Cretaceous rocks by palaeomagnetic studies of Misool $\left(18.5^{\circ} \mathrm{S}\right.$; Wensink et al., 1989). The declination is also similar to those of Santonian rocks on Misool indicating counter-clockwise rotations. We interpret this result, as Wensink et al. interpreted their Misool results, to indicate that Sula was some distance north of the Australian margin in the Late Cretaceous (Fig. 14). This conclu-

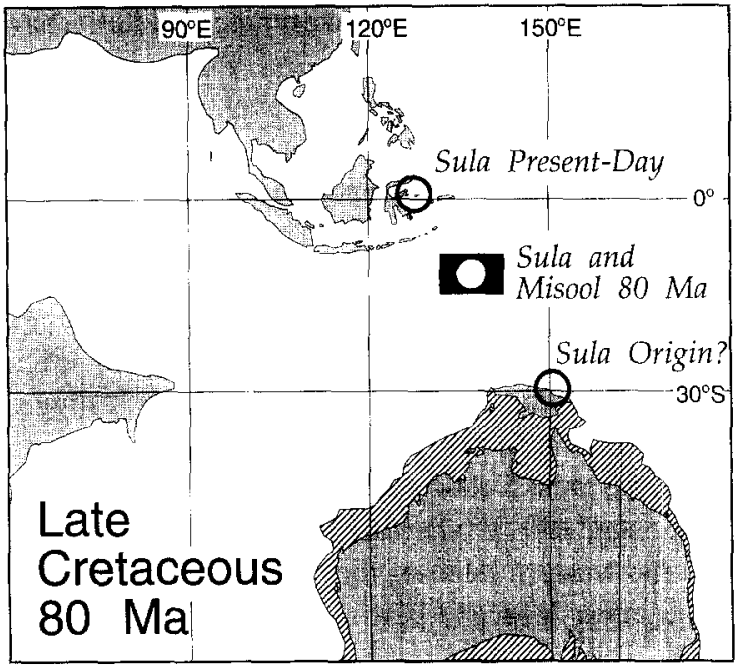

Fig. 14. Reconstruction of the $\sim 80 \mathrm{Ma}$ position of Australia, Misool and Sula. The latitude of Sula and Misool is known from palaeomagnetic results but the longitude is uncertain. The position on the Australian margin for Sula origin is based on Pigram et al. (1985).

sion implies that at least some of the Australian continental crust in the region separated from Australia before the Late Cretaceous as suggested by Pigram et al. (1985) and Wensink et al. (1989). However, the similarity in palaeolatitudes is surprising if Sula and Misool rifted from very different sites on the Australian margin as Pigram et al. have suggested.

\subsection{Neogene movement of the Sula Platform}

The Sula Platform is now attached to east Sulawesi and has a thrust contact with the east arm ophiolite; rocks of the ophiolite record palaeolatitudes of $\sim 20^{\circ} \mathrm{S}$ indicating an Indian Ocean (Mubroto et al., 1994) rather than a Philippine Sea Plate origin. Did the Sula Platform move west to its present position in the Sorong Fault Zone? Continental crust on Bacan and Obi became attached to the Philippine Sea Plate some time after $25 \mathrm{Ma}$ and subsequently moved large distances westward in the Sorong Fault Zone. However, these fragments are very small and are still part of, or close to, the Philippine Sea Plate. In contrast, the Sula Platform is a much larger crustal fragment and its western edge is today $\sim 200 \mathrm{~km}$ west of the Philippine Sea Plate. When did the Sula 
Platform collide with Sulawesi and could it have moved with the Philippine Sea Plate during the Neogene? There are a number of models that could explain the relationship between Sulawesi, the Sula Platform and the Sorong Fault system.

(1) It was originally suggested that the collision of the west Sulawesi Island arc and the Sula Platform resulted in ophiolite emplacement in the east arm (Kündig, 1956; Hamilton, 1979; Silver et al., 1983). However, recent evidence indicates that this suggestion is incorrect; the ophiolite was obducted westward onto west Sulawesi at the end of the Oligocene (Parkinson, 1991), whereas thrusting of the ophiolite onto the western edge of the Sula Platform occurred in the latest Miocene (Garrard et al., 1988; Davies, 1990). There is no record of Late Oligocene-Early Miocene deformation at the western edge of the Sula Platform (Davies, 1990) and furthermore, the Sula Platform could not have moved along the Sorong Fault since the fault did not form until $\sim 25 \mathrm{Ma}$.

(2) If ophiolite emplacement was unrelated to collision between the west arm and the Sula Platform the $\sim 5 \mathrm{Ma}$ unconformity may mark a collision between the already emplaced ophiolite and the Sula Platform. In this model, the Sula Platform could have moved along the Sorong Fault if it was sliced from the New Guinea margin and attached to the Philippine Sea Plate after $25 \mathrm{Ma}$. However, if Sula had been part of the New Guinea margin until 25 Ma, there should be deformation and a Miocene unconformity related to the Australia-Philippine Sea Plate collision. There is neither and Davies (1990) has shown that carbonate deposition continued from the Paleogene until the Late Miocene. This model also fails to explain the palaeomagnetic evidence discussed above which indicates that Sula had separated from Australia before the Late Cretaceous.

(3) Our preferred model is that the Sula Platform was a part of an independent microcontinental fragment which separated from Australia in the Mesozoic. This fragment included the Bird's Head, the Buton and Tukang Besi platforms, and the present islands of Misool, Buru and Seram. It was situated west of the Philippine Sea Plate and north of Australia (at the end of a proto-Banda Arc?). Sula collided with the east arm of Sulawesi as the result of convergence between Australia, the Philippine Sea Plate and Southeast Asia. It has no connection to ophiolite emplacement in Sulawesi. It was detached from the Bird's Head microcontinent in the Middle Miocene by a splay of the Sorong Fault and was transferred to the rotating Philippine Sea Plate for a few million years only before colliding with $\mathrm{Su}$ lawesi at the end of the Miocene. The kinematics of this process are discussed by Hall (1995) within a large scale reconstruction of Southeast Asia. Further evidence for this history is given by Charlton (1995). The similarity in Late Cretaceous palaeolatitudes of the east arm ophiolite and the Sula fragment may indicate that Sula has been close to the east Sulawesi ophiolite since the Mesozoic (Fig. 14). Neogene deformation at the contact between the ophiolite and the Sula platform is suggested to be the effect of shuffling of blocks in the decreasing area of the Eurasia-Australia-Pacific triple junction.

\section{Conclusions}

In all tectonic models of eastern Indonesia the Sorong Fault occupies a critical position. Until now there has been little evidence concerning the age of its initiation, the amount of displacement and the origin of fragments within the fault zone. The new palaeomagnetic results are the first quantitative data on the past position of plates and smaller crustal fragments in the region. They provide firm constraints for modelling the tectonic evolution of the Australia-Philippine Sea Plate boundary and for reconstructions of Southeast Asia.

The results of the new geological and palaeomagnetic work in the region show that the arc system which collided with the Australian margin at $25 \mathrm{Ma}$ belonged to the Philippine Sea Plate. The collision terminated convergence and may have been the cause of the major plate boundary reorganisation in the region. Ophiolites and volcanic arc rocks were emplaced on the Australian margin at about the same time as ophiolites were emplaced on the Sunda margin in Sulawesi (Parkinson, 1991). Northward motion of Australia has continued since $25 \mathrm{Ma}$ but the Australia-Philippine Sea Plate boundary has remained a strike-slip fault zone. This has been possible because rotation of the Philippine Sea Plate has caused it to move northwards at about the same rate as Australia. 
Post-collision strike-slip faulting may have dismembered the Philippine Sea arc fragments now preserved as "terranes" within the New Guinea orogenic belt. Similar arc and ophiolitic rocks now found in Bacan, Obi, Halmahera and Waigeo remained part of the Philippine Sea Plate and have rotated clockwise and moved westwards approximately $1500 \mathrm{~km}$ at an average rate of $\sim 6 \mathrm{~cm} / \mathrm{yr}$. The small continental areas of east Indonesia appear to have their origin in a single micro-continent which separated early from Australia by rifting as suggested by Pigram and Panggabean (1984) and which has been fragmented in the Neogene by splays of the Sorong Fault.

There is no advantage in regarding small fragments in the Sorong Fault Zone as terranes; such a hypothesis offers no explanations which are not provided by conventional plate tectonic modelling. However, on a small scale Obi can be described as a terrane in the sense that it is now a relatively large fragment separated from the adjacent plates by splays of the Sorong Fault system. During the Neogene Obi moved north with the Philippine Sea Plate. At the same time the northern part of the island rotated counter-clockwise whereas the southern part rotated clockwise. Obi is a composite fragment, including crust of Philippine Sea Plate and Australian origin, and has been deformed within a shear zone marking the boundary between the plates. Blocks within the fault zone are being "shuffled" westwards by the motion of the Philippine Sea Plate.

\section{Acknowledgements}

This work was supported by NERC award GR3/7149, and grants from the Royal Society and the University of London SE Asia Geological Research Group. We thank C.D. Anderson, S.J. Baker, F.T. Banner, T.R. Charlton, E.M. Finch, M. Fuller, E.A. Hailwood, H.Y. Ling, J.A. Malaihollo, G.J. Nichols and S.J. Roberts for discussions and their contributions to the Sorong Fault Project; S. Cisowski, J.R. Dunn, and P. Turner for advice and assistance with palaeomagnetic work; and C.C. Rundle and D.C. Rex for guidance and help with isotopic dating. Logistical assistance was provided by GRDC, Bandung and the Director, R. Sukamto with excel- lent field support by D.A. Agustiyanto, S. Atmawinata, A. Haryono, Kusnama, T. Padmawijadja, and S. Pandjaitan. Reconstructions were made using the Cambridge Paleomap ATLAS program.

\section{References}

Ali, J.R., 1989. Magnetostratigraphy of early Palaeogene sediments from NW Europe. Ph.D. Thesis. Univ. Southampton, Southampton, $277 \mathrm{pp}$.

Bain, J.H.C., 1973. A summary of the main structural elements of Papua New Guinea. In: P.J. Coleman (Editor), The Western Pacific: Island Arcs, Marginal Seas, Geochemistry. Westem Australia Univ. Press, Perth, pp. 147-161.

Baker, S.J. and Malaihollo, J.A.F., 1995. The chronology of Neogene igneous rocks in the Halmahera region: timing of arc initiation and development. In: R. Hall and D. Blundell (Editors), Tectonic Evolution of SE Asia. Geol. Soc. London Spec. Publ., in press.

Bleil, U., 1981. Paleomagnetism of DSDP Leg 60 sediments and igneous rocks from the Mariana region. Init. Rep. DSDP, 60 : 855-876.

Brouwer, H.A., 1924. Bijdrage tot de geologie der Obi-eilanden. Jaarb. Mijnw. Ned. Oost-Indie, 1923(52): 1-62.

Cardwell, R.K., Isacks, B.L. and Karig, D.E., 1980. The spatial distribution of earthquakes, focal mechanism solutions, and subducted lithosphere in the Philippine and northeastern Indonesian islands. In: D.E. Hayes (Editor), The Tectonic and Geologic Evolution of South-east Asian Seas and Islands. Am. Geophys. Union Geophys. Monogr., 23: 1-35.

Carey, S.W., 1958. A tectonic approach to continental drift. Symp. Continental Drift Proc., Hobart, pp. 177-355.

Charlton, T.R., 1986. A plate tectonic model of the eastern Indonesia collision zone. Nature, 319: 394-396.

Charlton, T.R., 1995. Correlation of the Salawati and Tomori Basins, eastern Indonesia: a constraint on left-lateral displacements in the Sorong Fault Zone. In: R. Hall and D. Blundell (Editors), Tectonic Evolution of SE Asia. Geol. Soc. London Spec. Publ., in press.

Charlton, T.R., Hall, R. and Partoyo, E., 1991. The geology and tectonic evolution of Waigeo Island, NE Indonesia. J. Southeast Asian Earth Sci., 6: 289-297.

Daly, M.C., Cooper, M.A., Wilson, I., Smith, D.G. and Hooper, B.G.D., 1991. Cenozoic plate tectonics and basin evolution in Indonesia. Mar. Pet. Geol., 8: 2-21.

Davies, I.C., 1990. Geological and exploration review of the Tomori PSC, eastern Indonesia. Proc. Indones. Pet. Assoc. 19th Annu. Conv., pp. 41-67.

DeMets, C., Gordon, R.G., Argus, D.F. and Stein, S., 1990. Current plate motions. Geophys. J. Int., 101: 425-478.

Dow, D.B., 1977. A Geological Synthesis of Papua New Guinea. Aust. Bur. Miner. Resour. Bull., 201, 39 pp.

Dow, D.B. and Sukamto, R., 1984. Western Irian Jaya: the end-product of oblique plate convergence in the late Tertiary. Tectonophysics, 106: 109-139. 
Dunn, J.R. and Fuller, M., 1984. Thermal demagnetization with measurements at high temperature using a SQUID magnetometer. EOS Trans. Am. Geophys. Union, 65: 863.

Fisher, R.A., 1953. Dispersion on a sphere. Proc. R. Soc. London A, 217: 295-305.

Fuller, M.D., Cisowski, S., Hart, M., Haston, R. and Schmidtke, E., 1988. NRM:IRM(s) demagnetisation plots; an aid to the interpretation of natural remanent magnetisation. Geophys. Res. Lett., 15: 518-521.

Garrard, R.A., Supandjono, J.B. and Surono, 1988. The geology of the Banggai-Sula microcontinent, eastem Indonesia. Proc. Indones. Pet. Assoc. 17th Annu. Conv., pp. 23-52.

Giddings, J.W., Klootwijk, C., Sunata, W., Loxton, C., Pigram, C.J. and Davies, H., 1984. Palaeomagnetism of Australia's active northern margin in New Guinea. 3rd Circum-Pacific Terrane Conference, Sydney (abstr.).

Giddings, J.W., Sunata, W. and Pigram, C.J., 1988. Palaeomagnetism of the Bird's Head, Irian Jaya. 9th Aust. Geol. Conv., Brisbane (abstr.).

Giddings, J.W., Sunata, W. and Pigram, C., 1993. Reinterpretation of palaeomagnetic results from the Bird's Head, Irian Jaya: new constraints on the drift history of the Kemum Terrane. Explor. Geophys., 24: 283-290.

Hall, R., 1987. Plate boundary evolution in the Halmahera region, Indonesia. Tectonophysics, 144: 337-352.

Hall, R., 1995. Reconstructing Cenozoic SE Asia. In: R. Hall and D. Blundell (Editors), Tectonic Evolution of SE Asia. Geol. Soc. London Spec. Publ., in press.

Hall, R. and Nichols, G.J., 1990. Terrane amalgamation in the Philippine Sea margin. Tectonophysics, 181: 207-222.

Hall, R., Audley-Charles, M.G., Banner, F.T., Hidayat, S. and Tobing, S.L., 1988a. The basement rocks of the Halmahera region, east Indonesia: a Late Cretaceous-Early Tertiary forearc. J. Geol. Soc. London, 145: 65-84.

Hall, R., Audley-Charles, M.G., Banner, F.T., Hidayat, S. and Tobing, S.L., 1988b. Late Paleogene-Quaternary Geology of Halmahera, Eastern Indonesia: initiation of a volcanic island arc. J. Geol. Soc. London, 145: 577-590.

Hall, R., Nichols, G.J., Ballantyne, P.D., Charlton, T. and Ali, J., 1991. The character and significance of basement rocks of the southern Molucca Sea region. J. Southeast Asian Earth Sci., 6: 249-258.

Hall, R., Ali, J.R. and Anderson, C.D., 1995a. Tertiary motion of the Philippine Sea Plate: palaeomagnetic evidence from Eastem Indonesia. Tectonics, in press.

Hall, R., Ali, J.R., Anderson, C.D. and Baker, S.J., 1995b. Origin and motion history of the Philippine Sea Plate. Tectonophysics, 251: 229-250, this issue.

Hamilton, W., 1979. Tectonics of the Indonesian region. US Geol. Surv. Prof. Pap., 1078, 345 pp.

Harland, W.B., Armstrong, R,. L., Cox, A.V., Craig, L.E., Smith, A.G. and Smith, D.G., 1990. A Geologic Time Scale, 1989. Cambridge Univ. Press, Cambridge, 263 pp.

Haston, R.B. and Fuller, M., 1991. Paleomagnetic data from the Philippine Sea Plate and their tectonic significance. J. Geophys. Res., 96: 6073-6098.

Haston, R.B., Stocking, L.B. and Ali, J.R., 1992. Palaeomagnetic data from holes 782A, 784A and 786A, Leg 125. Proc. ODP Sci. Results, 125: 535-545.

Hilde, T.W.C. and Lee, C-S., 1984. Origin and evolution of the West Philippine Basin: a new interpretation. Tectonophysics, 102: 85-104.

Hirooka, K., Takahasi, T., Sakai, H. and Nakajima, T., 1985. Paleomagnetic evidence of the northward drift of the Izu peninsula, central Japan. In: N. Nasu et al. (Editors) Formation of active ocean margins. Terrapub, Tokyo, pp. 775-787.

Jaques, A.L. and Robinson, G.P., 1977. The continent/island-arc collision in northem Papua New Guinea. BMR J. Aust. Geol. Geophys., 2: 289-303.

Keating, B.H. and Herrero, E., 1980. Paleomagnetic studies of basalts and andesites from DSDP Leg 59. Init. Rep. DSDP, 59: 533-544.

Kinoshita, H., 1980. Paleomagnetism of sediment cores from DSDP Leg 58, Philippine Sea. Init. Rep. DSDP, 58: 765-768.

Kodama, K., Keating, B.H. and Helsley, C.E., 1983. Paleomagnetism of the Bonin Islands and its tectonic significance. Tectonophysics, 95: 25-42.

Koyama, M., Cisowski, S.M. and Pezard, P., 1992. Paleomagnetic evidence for northward drift and clockwise rotation of the Izu-Bonin forearc since the Early Oligocene. Proc. ODP Sci. Results, 126: 353-370.

Kündig, E., 1956. Geology and ophiolite problems of East Celebes. Verh. K. Ned. Geol. Mijnbouwkd. Genoot. Geol. Ser., 16: 210-235.

Larson, E.E., Reynolds, R.L., Ozima, M., Aoki, Y., Kinoshita, H., Zasshu, S., Kawai, N., Nakajima, T., Hirooka, K., Merril, R. and Levi, S., 1975. Paleomagnetism of Miocene volcanic rocks of Guam and the curvature of the southern Mariana island arc. Geol. Soc. Am. Bull., 86: 346-350.

Letouzey, J., De Clarens, J., Guignard, J. and Berthon, J-L., 1983. Structure of the North Banda-Molucca area from multichannel seismic reflection data. Proc. Indones. Pet. Assoc. 12th Annu. Conv., pp. 143-156.

Louden, K.E., 1977. Paleomagnetism of DSDP sediments, phase shifting of magnetic anomalies and rotations of the West Philippine Basin. J. Geophys. Res., 82: 2989-3002.

Masson, D.G., Dwiyanto, B., Kallagher, H., Milsom, J.S. Nichols, G.J., Parsons, L. and Sikumbang, N., 1988. Active margin tectonics in eastern Indonesia - a study with GLORIA and underway geophysics. Inst. Oceanogr. Sci. Cruise Rep., 202, $20 \mathrm{pp}$.

McCabe, R. and Uyeda, S., 1983. Hypothetical model for the bending of the Mariana arc. In: D.E. Hayes (Editor), The Tectonic and Geologic Evolution of Southeast Asian Seas and Islands, 2. Am. Geophys. Union Geophys. Monogr., 27: 281293.

McCaffrey, R., 1982. Lithospheric deformation within the Molucca Sea arc-arc collision: evidence from shallow and intermediate earthquake activity. J. Geophys. Res., 87: 3663-3678.

McElhinny, M.W., 1964. Statistical significance of the fold test in palaeomagnetism. Geophys. J.R. Astron. Soc., 8: 338-40.

McFadden, P.L., 1990. A new fold test for paleomagnetic studies. Geophys. J. Int., 103: 163-169.

Moore, G.F. and Silver, E.A., 1983. Collision processes in the 
Northern Molucca Sea. In: D.E. Hayes (Editor), The Tectonic and Geologic Evolution of Southeast Asian Seas and Islands, 2. Am. Geophys. Union Geophys. Monogr., 27; 360-372.

Mubroto, B., Briden, J.C., McClelland, E. and Hall, R., 1994. Palaeomagnetism of the Balantak ophiolite, Sulawesi. Earth Planet. Sci. Lett., 125: 193-209.

Nichols, G.J. and Hall, R., 1991. Basin formation and Neogene sedimentation in a backarc setting, Halmahera, eastern Indonesia. Mar. Pet. Geol., 8: 50-61.

Parkinson, C.D., 1991. The petrology, structure and geologic history of the metamorphic rocks of central Sulawesi, Indonesia. Ph.D. Thesis. Univ. London, London, 333 pp.

Pieters, P.E., Pigram, C.J., Trail, D.S., Dow, D.B., Ratman, N. and Sukamto, R., 1983. The stratigraphy of western Irian Jaya. Geol. Res. Dev. Cent. Bull. Indones., 8: 14-48.

Pigram, C.J. and Davies, H.L., 1987. Terranes and the accretion history of the New Guinea orogen. BMR J. Aust. Geol. Geophys., 10: 193-211.

Pigram, C.J. and Panggabean, H., 1984. Rifting of the northern margin of the Australian continent and the origin of some microcontinents in Eastern Indonesia. Tectonophysics, 107: 331-353.

Pigram, C.J., Surono, Supandjono, J.B., 1985. Origin of the Sula Platform, eastern Indonesia. Geology, 13: 246-248.

Rangin, C., Jolivet, L., Pubellier, M. and the Tethys Pacific working group, 1990. A simple model for the tectonic evolution of southeast Asia and Indonesia region for the past 43 m.y. Bull. Soc. Géol, Fr. 6, 6: 889-905.

Ranken, B., Cardwell, R.K. and Karig, D.E., 1984. Kinematics of the Philippine Sea Plate. 'Tectonics, 3: 555-575.

Seno, T., Stein, S.A. and Gripp, A.E., 1993. A model for the motion of the Philippine Sea plate consistent with NUVEL-1 and geological data. J. Geophys. Res., 98: 17,941-17,948.

Shih, T-C., 1980. Marine magnetic anomalies from the western Philippine Sea: implications for the evolution of marginal basins. In: D.E. Hayes (Editor), The Tectonic and Geologic Evolution of Southeast Asian Seas and Islands. Am. Geophys. Union Geophys. Monogr., 23: 49-75.

Silver, E.A. and Moore, J.C., 1978. The Molucca Sea collision zone, Indonesia. J. Geophys. Res., 83: 1681-1691.
Silver, E.A. and Smith, R.B., 1983. Comparison of terrane accretion in modern Southeast Asia and the Mesozoic North American cordillera. Geology, 11: 198-202.

Silver, E.A., McCaffrey, R. and Smith, R.B., 1983. Collision, rotation, and the initiation of subduction in the evolution of Sulawesi, Indonesia. J. Geophys. Res., 88: 9407-9418.

Struckmeyer, H.I.M., Yeung, M. and Pigram, C.J., 1993. Mesozoic to Cainozoic plate tectonic and palaeogeographic evolution of the New Guinea Region. In: G.J. Carman and Z. Carman (Editors), Proc. 2nd PNG Pet. Conv., Port Moresby, pp. 261-290.

Sudana, D. and Yasin, A., 1983. Geological map of the Obi quadrangle, North Maluku. Geol. Res. Dev. Cent. Indones.

Thrupp, G. A, Slitter, M.V., Silver, E.A., Prasetyo, H. and Coe, R.S., 1987. Palaeomagnetic evidence from late Cretaceous rocks of Misool for rotation relative to Australia. EOS Trans. Am. Geophys. Union, 68: 1260.

Tjia, H.D., 1973. Irian Fault zone and Sorong melange. Sains Malays., 2: 13-30.

Tjokosapoetro, S. and Budhitrisna, T., 1982. Geology and tectonics of the northern Banda Arc. Geol. Res. Dev. Cent. Bull. Indones., 6: 1-17.

Van Bemmelen, R.W., 1949. The Geology of Indonesia. SDU, The Hague, $732 \mathrm{pp}$.

Vaquier, $V$ and Uyeda, S., 1967. Palaeomagnetism of nine seamounts in the western Pacific and of three volcanoes in Japan. Bull. Earthquake Res. Inst. Tokyo, 45: 815-848.

Visser, W.A. and Hermes, J.J., 1962. Geological results of the exploration for oil in Netherlands New Guinea. Verh. K. Ned. Mijnbouwkd. Genoot. Geol. Ser., 20, 265 pp.

Wanner, J., 1913. Zur Geologie der Inseln Obimajora und Halmahera in den Molukken. Neues Jahrb. Mineral. Geol. Palacontol., 36: 560-585.

Wensink, H., Hartosukohardjo, S. and Suryana, Y., 1989. Palaeomagnetism of Cretaceous sediments from Misool, northeastern Indonesia. Neth. J. Sea Res., 24: 287-301.

Zijderveld, J.D.A., 1967. A.C. demagnetization of rocks: analysis of results., In: D.W. Collinson, K.M. Creer and S.K. Runcorn (Editors), Methods in Paleomagnetism. Elsevier, Amsterdam, pp. 254-286. 